\title{
Growth Impacts of Income Inequality: Empirical Evidence From Nigeria
}

\author{
Ademola Obafemi Young ${ }^{1}$ \\ ${ }^{1}$ Department of Economics, Mountain Top University, Ogun State, Nigeria \\ Correspondence: Ademola Obafemi Young, Department of Economics, Mountain Top University, Ogun State, \\ Nigeria. Tel: 234-806-982-0390.
}

Received: August 27, 2019

Accepted: October 2, 2019

Online Published: November 30, 2019

doi:10.5430/rwe.v10n3p226

URL: https://doi.org/10.5430/rwe.v10n3p226

\begin{abstract}
The debate on whether income inequality promotes, restricts, or is independent of economic growth has been widely studied and discussed in development economics discourse. However, a careful reading of this extensive extant and burgeoning literature suggests that, other than the ambivalent nature and the fact that the bulk of these studies relied heavily on cross-section/-country/panel econometric analysis, empirical studies examining the nexus in the context of less developed economies, particularly, African countries, has received less attention, as most of the extant studies predominantly focused on developed economies. This current study, thus, attempts to examine the impact of inequality on growth in Nigeria spanning between the period 1970 and 2018. It also examined the theoretical predictions of some of the distinct transmission channels through which inequality impacts growth. Time series econometrics were applied. The results obtained consistently revealed that inequality hurts long-run growth in Nigeria. Also, the results obtained revealed that inequality in income increases relative redistribution and fertility, but lessens investment, gross enrollment ratio, and property rights protection in Nigeria, which may in turn impede growth.
\end{abstract}

Keywords: income inequality, economic growth, Gini Coefficient, Autoregressive Distributed Model, Nigeria

\section{Introduction}

Over the years, on the theoretical front, three distinct contentious and divergent views assessing the macroeconomic implications of inequality in the distribution income on economic growth have evolved markedly in development economics discourse, viz.: the classical, neoclassical and modern perspective theories. The classical expositions, whose ideas were grounded in the theories of economic growth put forward by Kaldor (1955) and Rostow (1959), on the one hand, posited that a certain degree of inequality in the distribution of income is essential, vital and beneficial to growth as well as overall economic performance (Aghion, Caroli, and Garcia-Penalosa, 1999; Panizza, 2002; Leoni and Pollan, 2003; Ehrhart, 2009; Galor, 2009). According to this body of literature, since the marginal propensity to save increases with wealth, inequality of income distribution channels resources towards individuals whose marginal propensity to save is higher (Galor, 2009), thereby trigger an increase in aggregate savings, and by extension raise capital accumulation, and correspondingly productivity growth (Leoni and Pollan, 2003; Delbianco, Dabus, and Caraballo, 2014; Kandek and Kajling, 2017; Njindan Iyke and Ho, 2017; Kennedy, Smyth, Valadkhani, and Chen, 2017; Joshi, 2018).

On the other hand, the neoclassical paradigm, which subsequently dominated the field of macroeconomics, implicitly dismissed the classical economists' viewpoint (Galor, 2009). Intrinsically, unlike the classical model, the neoclassical economists, whose standpoint can be traced to Kuznets' $(1955,1963)$ pioneering works of the inverted U-shaped curve nexus between economic growth and income inequality, vied that the study of inequality of income distribution has no significance in the understanding of growth process (Galor, 2009; Oded, 2011). Put differently, this strand of literature suggested that income inequality itself does not determine a country's economic growth course. Rather, it is economic growth that impacts income inequality, even more so than the latter affects the former (Oded, 2011; Joshi, 2018). Of late, in contrast to the predictions of the neoclassical and classical paradigms respectively: the modern perspective theory, initiated by Galor and Zeira $(1989,1993)$, reasoned that income distribution does, in fact, have a significant impact on economic growth (Galor and Zang, 1997; Dahan and Tsiddon, 1998; Ehrhart, 2009; Galor, 2009; Oded, 2011). Besides, unlike the classical standpoint, which highlighted the beneficial impacts of inequality for growth, the modern expositions underscored the potential adverse impacts of 
inequality on economic growth (Aghion and Bolton, 1992, 1997; Banerjee and Newman, 1993; Galor and Zeira, 1993; Pikketty, 1997; Galor, 2009).

On the empirical side, a replete of important empirical studies have attempted to assess the empirical implications of these three propositions. While some studies (Galor and Zeira, 1989, 1993; Alesina and Rodrik, 1994; Persson and Tabellini, 1994; Keefer-Knack, 1995; Birdsall, Ross, and Sabot, 1995; Perotti, 1994, 1996; Alesina and Perotti, 1993, 1996; Deininger and Squire, 1996, 1998; Knell, 1999; Mo, 2000; Barro, 2000; Rehme, 2002; De La Croix and Doepke, 2003; Banerjee and Duflo, 2003; Pagano, 2004; Knowles, 2005; Easterly, 2007; Sukiassyan, 2007; Noh and Yoo 2008; Lin, Huang, Kimz, Chih-ChuanYeh, 2009; Castelló-Climent, 2010; Chambers and Krause, 2010; Shin, 2012; Herzer and Vollmer, 2012; Wahiba and El Weriemmi, 2013; Fawaz, Rahnama, and Valcarcel, 2014; Cingano, 2014; Ostry, Berg, and Tsangarides, 2014; Darma and Ali, 2014; Bagchi and Svejnar, 2015; Njindan Iyke and Ho, 2017; Lahouij, 2017) lent credence to the modern perspective expositions which highlighted the potential negative impacts of inequality on growth process; in contrast, some other studies (Partridge, 1997; Li and Zou, 1998; Tanninen, 1999; Deininger and Olinto, 1999; Forbes, 2000; Balisacan and Fuwa, 2003; Iradian, 2005; De Dominicis, Florax and De Groot, 2008; Halter, Oechslin, and Zweimuller, 2014; Chletsos and Fatouros, 2016; Majeed, 2016a, 2016b; Naguib, 2017; Jauro, 2017; Joshi, 2018, etc.) have also reiterated the classical expositions which underscored the virtues of inequality of income distribution for economic growth.

Several other studies (Barro; 2000; Chang and Ram, 2000; Thornton, 2001; Panizza, 2002; Huang, 2004; Lin and Weng, 2006; Jalil, 2009; Chambers and Dhongde, 2011; Cheema and Rehman, 2014; Onaran and Oyvat, 2015; Vo, Nguyen, and Tran, 2019) are also quite supportive of the predictions of the neoclassical paradigm, particularly, with regard to the influence of growth on inequality. Still, a large number of studies (for instance, Furman and Stiglitz, 1998; Wan, Lu and Chen, 2006; Grijalva, 2011) found no clear relationship, different relationships at different time horizons (Partridge, 1997; Halter, Oechslin, and Zweimüller 2014; Malinen, 2013), or different relationships at different parts of the income distribution (Voitchovsky, 2005; Fallah and Partridge, 2007; Lin and Yeh, 2009; Assa, 2012; Tiwari, Shahbaz and Islam, 2013; Delbianco et al, 2014; Madsena, Islamb, and Doucouliagosc, 2016; Chen, 2018). Discursively, in accord with the theoretical discrepancies, even empirical evidences and literature, more often than not, still remain divided on the subject.

In Nigeria, as is the case in other parts of sub-Saharan Africa, income inequality, as measured by the widely-used Gini index, has grown up dramatically over the years. As of 1970, it was estimated at 0.0598 (World Income Inequality Database, WIID, 2018). Between 1978 and 1988, it rose from 0.0681 to 0.4025 (Awe and Ojo, 2012). Further, premised on the details published by the Standardized World Income Inequality Database (SWIID) of Solt (2016), it worsened from 0.4290 in 1990 to 0.4340 in 1995 before plummeted to 0.4220 in 2003 and remained unchanged till 2004. Regrettably, however, it deteriorated from 0.4174 in 2006 to 0.4810 in 2017 (Ewubare and Okpani, 2018). As evidenced in National Bureau of Statistics (2018) data set, it currently stands at 0.4870. In particular, it is projected to continue to rise over the next several decades (Mayah, Mariotti, Mere, and Odo, 2017). In this regard, the critical question is this: what are the growth implications of such rapid increase in income inequality in Nigeria? More precisely, as the gap between the haves and have-nots is increasingly widening with no end in sight in the country, what direction will the growth implications of inequality go? Explicitly, will an upsurge in inequality be beneficial/harmful for growth in Nigeria?

Although, as of date the literature hold a plethora of important empirical contributions on the subject, however, other than the ambivalent nature of these empirical findings and the fact that the bulk of these studies predominantly focused on developed countries and in addition provide little or no information about the distinct transmission channels through which inequality impacts growth, most of these extant studies examining the nature of the nexus relied heavily on cross-section/-country/panel econometric analysis. The problem with such discourse, as argued in Siddiqui and Ahmed (2009), besides the general methodological flaws relating to model specification and econometric procedure, is the homogenous assumption across the countries, which is unrealistic because of difference in culture, institutional, economic and social conditions. Given immense difference among countries with respect to nature and quality of data, cross-country comparison is fraught with danger (Siddiqui and Ahmed, 2009). In view of these, undoubtedly, there is the need not only to shed light on the existing contradiction-prone evidence but also to examine the subject from country-specific perspective. In the case of Nigeria, while there is a sizeable literature on income inequality and their economic implications as section two highlights, however, there is the dearth of econometric evidence examining the precise nexus linking inequality to growth and channels through which inequality impacts growth. This study, thus, will fill this gap. 
Following the introduction, the other sections of the paper is arranged as follows: section two depicts a review of the relevant literature on this theme, section three focuses on the model specification, data and methodology adopted in achieving the objectives of the study. In section four, the empirical results and discussions were presented. Finally, the fifth section presents the summary of the findings.

\section{Literature Review- A Synoptic View}

In spite of the extensive extant and burgeoning literature, the debate on whether income inequality promotes, restricts, or is independent of economic growth has remained a subject of controversy and yet to find a clear consensus in development economics discourse. Broadly speaking, there are three distinct contentious theoretical views to this debate, namely; the classical, neoclassical and modern perspective theories. The classical paradigm, on the one hand, argued that a certain degree of inequality of income distribution is essential, vital and beneficial to economic growth (see figure 1 in Appendix I). They (the classical economists) reasoned that since the marginal propensity to save increases with wealth, inequality channels resources towards individuals whose marginal propensity to save is higher (Galor, 2009), thereby trigger an increase in aggregate savings which can be channeled into investments that are conducive to growth (Cingano, 2014; Gründler and Scheuermeyer, 2015). In contrast to the classical standpoint, the neoclassical economists, inspired by the Kuznets' $(1955,1963)$ pioneering works of the inverted U-shaped curve nexus between growth and inequality, on the other hand, advanced the proposition that the study of income inequality has no significance in the understanding of growth process (Galor, 2009). Basically, this strand of literature implicitly interpreted the observed relationship between inequality and economic growth as capturing the effect of growth process on the distribution of income (Oded, 2011).

Of late, contrary to the predictions of the neoclassical and classical propositions respectively: the modern perspective theory, in contrast to the neoclassical expositions, advanced the novel standpoint that inequality of income distribution does, in fact, have a significant impact on economic growth (Galor, 2009; Oded, 2011). Also, unlike the classical paradigm which underlined the beneficial impacts of income inequality on growth, the modern expositions highlighted the potential adverse impacts of inequality of income distribution on growth (Bernstein, 2013; Stiglitz, 2016). Discursively, the strand of literature suggests four distinct transmission channels (see figure 1 in Appendix I) through which income inequality adversely impacts growth (Majeed, 2016a, 2016b). Firstly, as advanced by Galor and Zeira $(1989,1993)$, in the presence of credit market imperfections and fixed costs associated with the acquisition of education, inequality of income distribution may be detrimental to human capital formation and economic growth (Galor, 2009; Gründler and Scheuermeyer, 2015; Islam, 2017).

Secondly, in societies that are characterized by income inequality, distributional conflict may bias political decisions in favour of appropriation and may thus lessen investment and economic growth (Galor, 2009). Thirdly, as underscored by Alesina and Perotti (1996), "income inequality increases social discontent and fuels social unrest; the latter, by increasing the probability of coups, revolutions, mass violence or, more generally, by increasing policy uncertainty and threatening property rights, has a negative effect on investment, and, as a consequence, reduces growth" (Leoni and Pollan, 2003). Lastly, premised on a novel line of reasoning put forward by Becker and Barro (1988), a worsening in the inequality of wealth jointly generates an increase in the fertility rate and a drop in the rate of investment in human capital of most of the households which are poor and less educated, and this in turn hampers growth (Ehrhart, 2009).

On the empirical front, a replete of studies have attempted to assess the empirical implications of these three propositions. For the purpose of comprehension and simplicity, an overview and synopsis of more recent cross-country/-section/panel and time-series studies on the impact of income inequality on economic growth is presented in Table 1 (in Appendix II). As can be seen from the table, it evident that the macroeconomic implications of inequality on growth has been widely discussed. However, in spite of the large and burgeoning discourse on the nexus, empirically, studies have failed to suggest an overall dominance of one view over the other. While some studies lent credence to the modern perspective paradigm view which highlighted the potential negative impacts of inequality on the growth process, however, some other studies also reiterated the classical proposition which underscored the virtues of inequality of income distribution for economic growth. Several other studies are also quite supportive of the predictions of the neoclassical paradigm, particularly, with regard to the influence of growth on inequality. Still, a large number of studies found no clear relationship, different relationships at different time horizons, or different relationships at different parts of the income distribution. Besides, premised on the review depicted in the table, other than the ambivalent nature of the empirical findings, it is also apparent that the bulk of these studies predominantly focused on developed countries and regress growth on inequality without providing any pertinent information about the distinct transmission channels through which inequality impacts growth. 
Apart from these, as can be observed from the table, most of these empirical studies examining the exact nexus linking inequality to growth has relied heavily on cross-section/cross-country/panel econometric analysis. The problem with such discourse, as argued in Siddiqui and Ahmed (2009), aside the general methodological flaws relating to model specification and econometric procedure, is the homogenous assumption across the countries, which is unreasonable because of difference in culture, institutional, economic and social conditions. Given immense difference among countries with respect to nature and quality of data, cross-country comparison is fraught with danger (Siddiqui and Ahmed, 2009). Cross-country regressions are infamous for problem such as omitted variables bias, endogeneity, and so on. In the case of Nigeria, while there is a sizeable literature (Odedokun and Round, 2001; Akinbobola and Saibu, 2004; Dauda, 2004; Isere, Ibrahim and Agu, 2010; Awoyemi, and Omonona, 2011; Akpoilih and Farayibi, 2012; Awe and Ojo, 2012; Kolawole and Omobitan, 2015; Ogbeide and Agu, 2015; Adinde, 2017; Aigbokhan, 2008, 2017; Odusanya and Agboola, 2017; Ewubare and Okpani, 2018; Nwosa, 2019) on income inequality and their economic implications, however, there is the dearth of econometric evidence examining the precise nexus linking income inequality to economic growth and channels through which inequality impacts growth. This paper, thus, aims to fill this gap as there is the need not only to shed light on the existing contradiction-prone evidence but also to examine the subject from Nigeria perspective, a country that is characterized by high level of income disparities.

\section{Data, Model Specification and Methodology}

\subsection{Sources of Data}

The study made use of annual time series secondary data spanning between the period 1970 and 2018 sourced majorly from the publications of Central Bank of Nigeria Statistical Bulletin (2019), World Development Indicators (2019), United Nations Statistics Division National Accounts Main Aggregates Database (2019), Penn World Table 9.0, the Standardized World Income Inequality Database (SWIID, 2019), Economic Freedom of the World Index (Fraser Institute's Legal structure and security of property rights index), and United Nations University World Income Inequality Database WIID 3.4 (2019). The specific source and measurement as well as the description and justification for each variable employed in the study are depicted in Table 2 in Appendix II. In instance, where there are some missing observations, the study, following Ogbeide and Agu (2015), filled the missing gap using 4-year moving average, a widely accepted method of extrapolation.

\subsection{Econometric Model}

In order to obtain an econometric model used in examining whether income inequality has growth-promoting or growth-dampening impacts in Nigeria, this study draws on the theoretical framework of neoclassical growth model (though augmented by certain improvements and extensions taking into cognizance the objective of the study) and specifies a Cobb-Douglas production function of the form:

$$
Q=\phi K^{\alpha} L^{1-\alpha} \quad 0<\alpha<1
$$

where $Q, K, \mathrm{~L}, \phi$ and $\alpha$ are aggregate output, physical capital stock, labour force, technological progress (i.e. total factor productivity) and elasticity of output with respect to capital respectively. Notice that technological progress that enters in this fashion is known as Hicks-neutral. Following the literature (for instance, Bloom, Canning and Malaney, 1999), suppose the endogenous processes which generate total factor productivity (TFP hereafter) and physical capital accumulation converge to a steady state, this leads us to specify equation (1) in an intensive form \{by dividing both sides of equation 1 by $L$ \} as follows

$$
\left(\frac{Q}{L}\right)^{*}=\phi\left(\frac{K^{*}}{L}\right)^{\alpha} \Rightarrow q^{*}=\phi k^{* \alpha}
$$

where $^{*}$ depicts the variable's steady state value. Suppose this steady-state value $\left(q^{*}\right)$ is determined by a set of factors, Z, (that is a matrix of variables) that may affect physical capital accumulation and TFP. That is,

$$
q^{*}=\mathrm{Z} \beta
$$


Given the model (3), the regression equation derived from this model assumes that the actual level of income per worker will adjust slowly from its initial level to this steady-state level as follows:

$$
g_{(q)}=\lambda\left(q^{*}-q\right)
$$

where $g_{(q)}$ denotes growth rate of income per worker, $q^{*}$ depicts natural log of the steady state of income per worker, $q$ is the natural $\log$ of the initial income per worker and $\lambda$ represents the rate of convergence. The empirical implementation of equation (4) suggests that a country's rate of growth is directly proportional to the initial distance from its steady-state income level $q^{*}$. As such, the poorer a country is with respect to its steady state, the faster such country is expected to grow (Bloom et al, 1999). By substituting equation (3) into equation (4)

$$
g_{(q)}=\lambda(\mathrm{Z} \beta-q)
$$

where $\beta$ is a vector of parameters. By combining equation (4) \{i.e. the steady-state equation\} with equation (5) \{i.e. the adjustment process\} and adding a random error $\mathcal{E}$ yields the following equation whose parameters can be estimated.

$$
g_{(q)}=\hbar Z \beta-\hbar q+\varepsilon
$$

Equations (1-6) provide the theoretical underpinnings of most recent empirical studies of the sources of economic growth. Since income per capita instead of income per worker is usually used for growth regressions, the relationship between working-age population, total population, and labour force needs to be taken into account. Using the fact that

$$
\begin{gathered}
q=\frac{Q}{N} \frac{N}{L}=\stackrel{\wedge}{L} \\
q=\stackrel{\wedge}{q} \frac{N}{L} \\
\Lambda \\
q=q \frac{L}{N}
\end{gathered}
$$

where $\hat{q}$ represents income per capita, and $N$ denotes to total population. By combining equations (6) and (9) in order to obtain an expression for income per capita:

$$
\begin{gathered}
g_{\left(\begin{array}{c}
\Lambda \\
q
\end{array}\right)}=g_{(q)}+g_{(L)}-g_{(N)} \\
g_{\left(\begin{array}{c}
\Lambda \\
q
\end{array}\right)}=\hbar(\mathrm{Z} \beta-q)+g_{(L)}-g_{(N)}+\varepsilon_{2}
\end{gathered}
$$

where $g_{\left(\begin{array}{c}\Lambda \\ q\end{array}\right)}, g_{(L)}$ and $g_{(N)}$ are growth rates of income per capita, labour force and population respectively. By simplifying, thus, an econometric representation of the expression in equation (11): 


$$
g_{\left(\begin{array}{c}
\Lambda \\
q
\end{array}\right)}=\rho_{0}+\rho_{1} q+\rho_{2} g_{(L)}+\rho_{3} g_{(N)}+\rho_{4} Z+\varepsilon_{3}
$$

The empirical implementation of equation (12) suggests, thus, that the growth rate of income per capita depends on initial income per worker, growth rates of labour force and population and a set of factors, $Z$, that determined the steady state level of income respectively. To close the model there is the need for covariates variables in vector $Z$ to be defined. In the theoretical and empirical literature on the analysis of macroeconomic determinants of economic growth, econometric literature points to a number of robust and potential important long-term variables. For simplicity, this study follows Islam (2017) in the selection of the covariates variables included in $Z$. These variables are the financial deepening, human capital accumulation, and trade openness.

Regarding the impact of financial deepening on economic growth, Jalilian and Kirkpatrick (2005) emphasized the intermediation role performed by financial institutions in bridging the information asymmetries between borrowers and savers, thereby performing the functions of savings mobilization, capital fund allocation, monitoring of the use of funds, and managing risk, which together support the economic growth process (Levine, 1997; Jalilian and Kirkpatrick, 2005). Human capital accumulation, as argued in Benhabib and Spiegel (1994), does not only enhance the ability of a country to develop its own technological innovation, but also increases its ability to adapt existing knowledge which is one of the robust determinants of growth (Islam, 2017). Keho (2017) reasoned that trade openness can potentially enhance economic growth by providing access to goods and services, achieving efficiency in the allocation of resources and improving total factor productivity through technology diffusion and knowledge dissemination (Rivera-Batiz and Romer, 1991; Barro and Sala-i-Martin, 1997). Finally, in order to examine whether inequality has growth-promoting or growth-dampening impacts in Nigeria, the study incorporate Gini coefficient of income distribution. Hence, in line with these arguments, an econometric representation of equation (12) is then specified as follows:

$$
\partial \ln \hat{q}_{t}=\lambda_{0}+\lambda_{1} \ln q_{t}+\lambda_{2}\left(\partial \ln L_{t}\right)+\lambda_{3}\left(\partial \ln N_{t}\right)+\lambda_{4} \ln F_{t}+\lambda_{5} \ln H_{t}+\lambda_{6} \ln T_{t}+\lambda_{7} \ln G_{t}+\mu_{t}
$$

where $\partial \ln \hat{q}, \ln q_{t},\left(\partial \ln L_{t}\right),\left(\partial \ln N_{t}\right), \ln F_{t}, \ln H_{t}, \ln T_{t}, \ln G_{t}$, and $\mu_{t}$ are the growth rate of income per capita, income per worker, growth rate of labour force, growth rate of population, financial deepening, human capital accumulation, trade openness, Gini coefficient, and white-noise error term respectively. $\lambda_{i}$ (for $i=1, \ldots, 7$ ) are the shares of these inputs in the aggregate output, $\lambda_{0}$ is the constant term, $t$ denotes time, $\ln$ is the natural logarithm operator. The variables are transformed to their natural logarithm form to remove or lessen considerably any heteroskedasticity in the residuals of the estimated model.

One of the limitations of equation (13) is that it does not permit policymakers to differentiate and separate the short-run contribution of the covariates variables, to the overall growth process, from the long-run contribution. Whereas growth policies are targeted toward achieving long-run results, production decisions take into account the short-run impact of the determinants of production (Njindan Iyke and Ho, 2017). Besides, it also takes time before policies such as the structural reforms actually affect the lives of the poor and growth. As a result, there may possibly be long lags between the time policies are implemented and their impacts on economic variables (Agyemang, 2014). Hence, by neglecting the short-run dynamics of the determinants to the overall growth process, vital key insights are lost. As well, Beck and Katz (1996) reasoned that the inclusion of lag dependent variable as a regressor in the model is also a parsimonious way to account for the continuing effect of explanatory variables in the past (Agyemang, 2014). Hence, in order to allow for some degree of persistence in the data generating process, equation (13) is then modified as a dynamic Autoregressive Distributed Lag (ARDL) to include the lag dependent and independent variables as follows: 


$$
\begin{aligned}
& \Delta\left(\partial \ln q_{t}\right)=\theta_{0}+\sum_{i=1}^{a} \theta_{1 i} \Delta\left(\partial \ln \hat{q}_{t-i}\right)+\sum_{i=0}^{b} \theta_{2 i} \Delta \ln q_{t-i}+\sum_{i=0}^{c} \theta_{3 i} \Delta\left(\partial \ln L_{t-i}\right)+\sum_{i=0}^{d} \theta_{4 i} \Delta\left(\partial \ln N_{t-i}\right)+\sum_{i=0}^{e} \theta_{5 i} \Delta \ln F_{t-i}+\sum_{i=0}^{f} \theta_{6 i} \Delta \ln H_{t-i} \\
& +\sum_{i=0}^{g} \theta_{7 i} \Delta \ln T_{t-i}+\sum_{i=0}^{h} \theta_{8 i} \Delta \ln G_{t-i}+\delta_{1}\left(\partial \ln \hat{q}_{t-1}\right)+\delta_{2} \ln q+\delta_{3}\left(\partial \ln L_{t-1}\right)+\delta_{4}\left(\partial \ln N_{t-1}\right)+\delta_{5} \ln F_{t-1}+\delta_{6} \ln H_{t-1}+\delta_{7} \ln T_{t-1} \\
& +\delta_{8} \ln G_{t-1}+\mu_{1 t}
\end{aligned}
$$

Notice that the terms with summation signs are used to model the short-run dynamics structure. Equation (14) is $A R D L$ of order $(a, b, c, d, e, f, g, h)$ which holds that economic growth is predisposed to be determined by its own lag, the lag values of initial income per worker, growth rate of labour force, growth rate of population, financial deepening, human capital accumulation, trade openness, and Gini coefficient. The $\delta^{\prime} s$ denote the long run dynamics whereas $\theta^{\prime} s$ depict the short-run dynamics of the model. In addition, $\triangle$ represents the first difference operator, $\theta_{0}$ is the drift component and, $u_{1 t}$ is white noise residual.

Further, Majeed (2016a, 2016b) argued that, in an attempt to conduct the estimation of econometric model (14), it is likely that income inequality specified in the model captures the impact of poverty on growth. As such, there is the need to assess the exclusive impact of income inequality on economic growth. Thus, following Majeed (2016a, 2016 b), this study controls for poverty incidence in a separate regression. Hence, in equation (15), $\ln P$ (a measure for poverty incidence proxied by headcount ratio) is incorporated as an additional term in order to capture the true growth impacts of income inequality.

$$
\begin{aligned}
& \Delta\left(\partial \ln q_{t}\right)=\theta_{0}+\sum_{i=1}^{a} \theta_{1 i} \Delta\left(\partial \ln \hat{q}_{t-i}\right)+\sum_{i=0}^{b} \theta_{2 i} \Delta \ln q_{t-i}+\sum_{i=0}^{c} \theta_{3 i} \Delta\left(\partial \ln L_{t-i}\right)+\sum_{i=0}^{d} \theta_{4 i} \Delta\left(\partial \ln N_{t-i}\right)+\sum_{i=0}^{e} \theta_{5 i} \Delta \ln F_{t-i}+\sum_{i=0}^{f} \theta_{6 i} \Delta \ln H \\
& +\sum_{i=0}^{g} \theta_{7 i} \Delta \ln T_{t-i}+\sum_{i=0}^{h} \theta_{8 i} \Delta \ln P_{t-i}+\sum_{i=0}^{j} \theta_{9 i} \Delta \ln G_{t-i}+\delta_{1}\left(\partial \ln \hat{q}_{t-1}\right)+\delta_{2} \ln q+\delta_{3}\left(\partial \ln L_{t-1}\right)+\delta_{4}\left(\partial \ln N_{t-1}\right)+\delta_{5} \ln F_{t-1}+ \\
& \delta_{6} \ln H_{t-1}+\delta_{7} \ln T_{t-1}+\delta_{8} \ln P_{t-1}+\delta_{9} \ln G_{t-1}+\mu_{3 t}
\end{aligned}
$$

It is expected a priori that the growth rate of labour force, financial deepening, human capital accumulation, initial income per worker and trade openness will enhance the growth rate of income per capita. Expectedly, the relationship between these explanatory variables and economic growth is positive, while the poverty incidence is detrimental to growth, thus, the expected a priori is negative. Income inequality and the growth rate of population may or may not benefit economic growth, as such the expected a priori is either positive or negative respectively.

Additionally, in order to strengthen the robustness of this analysis, an attempt is also made to examine the classical economists and modern expositions predictions of some of the distinct transmission channels (viz., the investment, fertility, schooling, fiscal policy and socio-political instability channels) through which inequality (might positively or adversely) impacts growth. Regarding the investment channel, the classical economists submitted that income inequality stimulates economic growth by fostering aggregate saving and investment (Gründler and Scheuermeyer, 2015). In contrast to the classical standpoint, the modern expositions paradigms reasoned that investment will be adversely affected by inequality in the presence of credit market imperfections and fixed costs associated with investment (Islam, 2017). As regards socio-political instability channels, Alesina and Perotti (1996) argued that "income inequality increases social discontent and fuels social unrest; the latter, by increasing the probability of coups, revolutions, mass violence or, more generally, by increasing policy uncertainty and threatening property rights, has a negative effect on investment, and, as a consequence, lessens growth" (Leoni and Pollan, 2003).

In relation to fertility and schooling channels, De La Croix and Doepke (2003) vied that fertility and education decisions are interdependent: countries with higher income inequality tend to experience a higher fertility differential and lower average education which in turn lessen the future growth rate (De La Croix and Doepke, 2003; Ehrhart, 2009; Islam, 2017). With reference to fiscal policy channel, Alesina and Rodrik (1994) and Persson and Tabellini (1994) maintained that higher inequality in income and wealth in a democratic society may result in higher taxation and redistributive economic policies that decrease investment and subsequently economic growth (Islam, 2017). Progressive taxation and fiscal redistribution create a general disincentive to work and invest, hence the rich will lobby against the implementation of efficient redistribution policies (Benabou, 2002; Acemoglu and Robinson, 2008; Islam, 2017). 
Hence, in line with these aforementioned arguments, in order to provide an insight on some of the distinct transmission channels through which inequality might impact growth, this study (following Islam, 2017; Lahouij, 2017), considered investment rate (INV, the ratio of fixed investment to RGDP), total fertility rate (FER), property rights protection (PRP), human capital accumulation (HCA), and relative redistribution (RED, calculated as the ratio of the difference between market Gini and net Gini to the market Gini) and specified the following unrestricted error correction (UECM) ARDL models:

$$
\begin{aligned}
& \Delta\left(\partial \ln I N_{t}\right)=\alpha_{0}+\sum_{i=1}^{a} \alpha_{1 i} \Delta\left(\partial \ln I N_{t-i}\right)+\sum_{i=0}^{b} \alpha_{2 i} \Delta \ln F_{t-i}+\sum_{i=0}^{c} \alpha_{3 i} \Delta \ln H_{t-i}+\sum_{i=0}^{d} \alpha_{4 i} \Delta \ln T_{t-i}+\sum_{i=0}^{e} \alpha_{5 i} \Delta\left(\partial \ln q_{t-i}^{\Lambda}\right)+\sum_{i=0}^{f} \alpha_{6 i} \Delta \ln G_{t-i}+ \\
& \beta_{1}(\partial \ln I N)_{t-1}+\beta_{2}(\ln F)_{t-1}+\beta_{3}(\ln H)_{t-1}+\beta_{4}(\ln T)_{t-1}+\beta_{5}\left(\partial \ln \hat{q}_{t-1}\right)+\beta_{6}(\ln G)_{t-1}+\varepsilon_{0 t} \\
& \Delta\left(\partial \ln F R_{t}\right)=\delta_{0}+\sum_{i=1}^{p} \delta_{1 i} \Delta\left(\ln F R_{t-i}\right)+\sum_{i=0}^{q} \delta_{2 i} \Delta \ln F_{t-i}+\sum_{i=0}^{r} \delta_{3 i} \Delta \ln H_{t-i}+\sum_{i=0}^{s} \delta_{4 i} \Delta \ln T_{t-i}+\sum_{i=0}^{t} \delta_{5 i} \Delta\left(\partial \ln q_{t-i}\right)+\sum_{i=0}^{u} \delta_{6 i} \Delta\left(\partial \ln M R_{t-i}\right) \\
& \sum_{i=0}^{v} \delta_{7 i} \Delta \ln G_{t-i}+\rho_{1}(\partial \ln F R)_{t-1}+\rho_{2}(\ln F)_{t-1}+\rho_{3}(\ln H)_{t-1}+\rho_{4}(\ln T)_{t-1}+\rho_{5}\left(\partial \ln \hat{q}_{t-1}\right)+\rho_{6}(\partial \ln M R)_{t-1}+\rho_{7}(\ln G I N)_{t-1}+\varepsilon_{l t} \\
& \Delta \ln H_{t}=\eta_{0}+\sum_{i=1}^{q} \eta_{1 i} \Delta \ln H_{t-i}+\sum_{i=0}^{w} \eta_{2 i} \Delta \ln F_{t-i}+\sum_{i=0}^{e} \eta_{3 i} \Delta \ln F R_{t-i}+\sum_{i=0}^{r} \eta_{4 i} \Delta \ln T_{t-i}+\sum_{i=0}^{t} \eta_{5 i} \Delta\left(\partial \ln \hat{q}_{t-i}^{\Lambda}\right)+\sum_{i=0}^{y} \eta_{6 i} \Delta \ln G_{t-i}+ \\
& \gamma_{1}(\ln H)_{t-1}+\gamma_{2}(\ln F)_{t-1}+\gamma_{3}(\ln F R)_{t-1}+\gamma_{4}(\ln T)_{t-1}+\gamma_{5}\left(\partial \stackrel{\Lambda}{\Lambda} \hat{q}_{t-1}\right)+\gamma_{6}(\ln G I N)_{t-1}+\varepsilon_{2 t} \\
& \Delta \ln R D_{t}=\partial_{0}+\sum_{i=1}^{j} \partial_{1 i} \Delta \ln R D_{t-i}+\sum_{i=0}^{k} \partial_{2 i} \Delta \ln F_{t-i}+\sum_{i=0}^{l} \partial_{3 i} \Delta \ln H_{t-i}+\sum_{i=0}^{m} \partial_{4 i} \Delta \ln T_{t-i}+\sum_{i=0}^{n} \partial_{5 i} \Delta\left(\partial \ln q_{t-i}\right)+\sum_{i=0}^{o} \partial_{6 i} \Delta \ln G_{t-i}+ \\
& \varphi_{1}(\ln R D)_{t-1}+\varphi_{2}(\ln F)_{t-1}+\varphi_{3}(\ln H)_{t-1}+\varphi_{4}(\ln T)_{t-1}+\varphi_{5}\left(\partial \ln \hat{\Lambda}_{t-1}\right)+\varphi_{6}(\ln G)_{t-1}+\varepsilon_{3 t} \\
& \Delta \ln P R_{t}=\ell_{0}+\sum_{i=1}^{g} \ell_{1 i} \Delta \ln P R_{t-i}+\sum_{i=0}^{h} \ell_{2 i} \Delta \ln F_{t-i}+\sum_{i=0}^{j} \ell_{3 i} \Delta \ln H_{t-i}+\sum_{i=0}^{k} \ell_{4 i} \Delta \ln T_{t-i}+\sum_{i=0}^{x} \ell_{5 i} \Delta\left(\partial \ln q_{t-i}^{\Lambda}\right)+\sum_{i=0}^{z} \ell_{6 i} \Delta \ln G_{t-i}+ \\
& \sigma_{1}(\ln P R)_{t-1}+\sigma_{2}(\ln F)_{t-1}+\sigma_{3}(\ln H)_{t-1}+\sigma_{4}(\ln T)_{t-1}+\sigma_{5}\left(\partial \ln q_{t-1}\right)+\sigma_{6}(\ln G)_{t-1}+\varepsilon_{4 t}
\end{aligned}
$$

where $I N$ is investment rate, $F$ is financial deepening, $H$ is human capital accumulation, $T$ is trade openness,

$\partial \ln \hat{q}$ is growth rate of income per capita, $G$ is Gini coefficient, $F R$ is fertility rate, $M R$ is infant mortality rate, $R D$ is relative redistribution, $P R$ is property rights protection; while the $\beta^{\prime} s, \rho^{\prime} s, \gamma^{\prime} s, \varphi^{\prime} s$, and $\sigma^{\prime} s$ depict the long-run impacts, the $\alpha^{\prime} s, \delta^{\prime} s, \eta^{\prime} s, \partial^{\prime} s$, and $\ell^{\prime} s$ capture the short-run elasticities of the models.

Also, $\Delta$ denotes the first difference operator, $\alpha_{0}, \delta_{0}, \eta_{0}, \partial_{0}$, and $\ell_{0}$ are the drift components and, $\varepsilon_{i t}$ (for $i=0, \ldots 4)$ is white noise residual. 


\subsection{Techniques of Estimation and Method of Data Analysis}

Discursively, in order to estimate the short-run and long-run elasticities coefficients of equations (14-20), a four-stage procedure was followed. In the first stage, the order of integration of the variables were determined using Augmented Dickey-Fuller (ADF) and the Phillips Perron (PP) unit root tests to avoid spuriousness of the empirical findings. In the second stage, following the literature, the structural lags were determined on the basis of Hannan-Quinn information criteria (HQ), the Akaike information criteria (AIC), the Schwarz information criteria (SIC), the Log Likelihood (LL) and the Final Prediction Error (FPE). This is important since, under parameterization would lead to a biased result and similarly, over-parameterization reduces the power of the tests. Following the suggestion of Granger (1988), in the third stage, a test of possible cointegrating relationship among the series was conducted. In the literature, several techniques are available for conducting cointegration tests. Generally used techniques comprise the residual based Engle-Granger (1987) test, Gregory and Hansen (1996), Johansen (1988), and Johansen-Juselius (1990). Of late, the proposed autoregressive distributed lag (ARDL) approach, developed by Pesaran and Shin (1995, 1998), Pesaran, Shin and Smith $(1996,2001)$ has become popular (Verma, 2007).

Basically, this study, following Hundie (2014), adopts the ARDL Bounds Testing Approach. This technique is based on the estimation of an Unrestricted Error Correction Model (UECM) which enjoys several advantages over the conventional type of cointegration techniques. Firstly, it can be applied irrespective of the order of integration (and in small samples) while other cointegration techniques require all variables be of equal degree of integration (and large samples) (Verma, 2007). Secondly, given the nature of interrelation among the growth rate of capital per worker, the growth rate of effective labour force, the growth rate of population, human capital accumulation, financial deepening, trade openness, and Gini coefficient, which are included in our models, the Bounds Testing Approach is suitable to address possible endogeneity problems. Thirdly, as noted by Pesaran and Shin (1998), appropriate modification of the orders of the ARDL model is sufficient to simultaneously correct the residual serial correlation and the problem of endogenous regressors (Samantaraya and Patra, 2014). Finally, the bounds testing is more robust and perform better for small sizes.

Hence, having estimated our UECM-ARDL models (14-20), the presence of cointegrating relationship among the variables was evaluated by testing for the joint significance of the estimated coefficients of the lagged levels of the variables in the equations (14-20) using the Wald test based on the standard $F$-statistic. The F-statistic values derived from this test were compared with two sets of critical values (lower and upper bound) for a given level of significance reported in Pesaran, Shin and Smith (2001) and Nayaran (2005) for large samples and small sample sizes, respectively. Notice that the upper bound values assume that the variables are I(1) while the lower bound values assume that all variables in our ARDL models are $\mathrm{I}(0)$. Thus, if the computed $F$-statistic is less than the lower bound value, the null hypothesis of no cointegrating is not rejected. On the contrary, if the computed $F$-statistics is greater than the upper bound value, it implies existence of long-run relationship among the variables. Finally, if the computed $F$ - statistics lies between the lower bound and upper bound, long run association between the variables becomes inconclusive. Under the inconclusive cases, following Kremers, Ericsson and Dolado (1992) and Bannerjee, Dolado and Mestre (1998), the error correction term will be a useful way of establishing cointegration (Verma, 2007).

Once a long-run cointegrating relationship has been confirmed, hereafter in stage four, the long-run and short-run parameters associated with the ARDL models (14-20) were estimated. In addition, a variety of diagnostics and stability tests which will enhance the credibility of the ARDL models were carried out. In particular, in order to ensure that the models possess the desirable BLUE properties, different post-estimation diagnostic tests were carried out, including the Breusch-Godfrey serial correlation LM test, the ARCH heteroskedasticity test, the Jacque-Bera normality test and the Ramsey RESET specification test. The cumulative sum of recursive residuals (CUSUM) and the cumulative sum of recursive residual squares (CUSUMSQ) were also plotted to determine if the models are stable.

\section{Empirical Results and Discussion}

\subsection{Descriptive Statistics, Unit Root, Optimal Lag Length Selection and Bounds Test Results}

As a preliminary examination, before the detailed analysis and estimation of the ARDL models (14-20) were undertaken, the study analyzed the descriptive statistics of the variables under consideration. This is done in order to ascertain the statistical properties of the variables. The results obtained are presented in table 3 (in Appendix II). As it is depicted in the table, the mean and the median of all the variables in the data set displayed a high consistency as their mean and median values are within the minimum and maximum values of the series. Besides, all the data series have the values of their mean and median almost the same. This shows that the distribution is nearly symmetrical. 
This is in line with the position of Karmel and Polasek (1980) that when a distribution is perfectly symmetrical, the mean, median and the mode must converge. Moreover, the low standard deviation of nearly all the data series indicates that the deviations of actual data from their mean values are very small. Further, the skewness statistic (a measure of asymmetry of the distribution of the series around the mean), kurtosis statistic (a measure of thickness of the tail of the distribution) and Jarque-Bera (JB) statistic which is used to test the null hypothesis where each variable is considered to have a normal distribution showed that all the variables are normally distributed. The normality is further buttressed by the nearness of the mean and median values for these series.

Following the examination of the descriptive statistics of the variables employed, in order to avert spurious results and also ensure that none of the variables are integrated of order two I(2), the study established the stationarity status of the employed variables. To this end, the study applied two types of formal tests, viz.: the Augmented Dickey-Fuller (ADF) and the Phillips-Perron (PP) tests to determine the order of integration of the series under consideration. The choice of these two tests statistics is informed by the fact that both tests control for higher-order autocorrelation. Both tests statistics were done for two alternative specifications at 10 percent, 5 percent and 1 percent level of significance. At the outset, it was tested with intercept but no trend, and then it was tested with both intercept and trend. The estimated results of the ADF and PP tests statistics are depicted in tables 4 and 5 (in Appendix II) respectively. As can be observed from the tables both tests consistently revealed that other than the growth rate of income per capita, growth rate of labour force and investment rate which are stationary at level, all other variables (income per worker, growth rate of population, financial deepening, human capital accumulation, trade openness, Gini Index, poverty incidence, fertility rate, mortality rate, relative redistribution and property rights protection) become stationary when converted to first differences, suggesting that each is integrated of order one, denoted as I (1), at 5 percent level of significance.

Having investigated the descriptive statistics and order of integration of the series, the study proceeded to determine the appropriate lag length incorporated for each variable in the ARDL models (14-20) on the basis of Hannan-Quinn information criteria (HQ), the Akaike information criteria (AIC), the Schwarz information criteria (SIC), the Log Likelihood (LL) and the Final Prediction Error (FPE). The results obtained are presented in table 6 (in Appendix II). To choose the appropriate lag length, Liew (2004) reasoned that the Akaike Information Criterion (AIC) and Final Prediction Error (FPE) are superior than the other criteria under study in the case of small sample (60 observations and below), in the manners that they minimize the chance of under estimation while maximizing the chance of recovering the true lag length. Hence, given that there were 49 observations, the optimal lag lengths 2 (for models 14-18) and 1 (for models 19-20) were carefully chosen.

Hereafter, with these maximum lag lengths setting, during the analysis 4,374 different ARDL models specifications for equation 14; 13,122 different ARDL models specifications for equation 15; 486 different ARDL models specifications for equation 16; 1,458 different ARDL models specifications for equation 17; 486 different ARDL models specifications for equation 18; 32 different ARDL models specifications for equation 19; and 32 different ARDL models specifications for equation 20 were considered and the most suitable model ARDL $(2,0,2,1,0,0,0,0)$ for equation 14 , ARDL $(1,1,0,1,0,2,2,1,1)$ for equation 15 , $\operatorname{ARDL}(2,0,2,2,2,1)$ for equation 16 , ARDL $(2,0,0,0,0,0,0)$ for equation 17, $\operatorname{ARDL}(1,0,0,0,0,2)$ for equation 18, $\operatorname{ARDL}(1,0,0,0,0,1)$ for equation 19 , and $\operatorname{ARDL}(1,0,1,0,0,0)$ for equation 20 were selected for this study. Figures 2-8 (in Appendix I) which provide graphs of the AIC of the top twenty models (for models 14-20 respectively) depict the relative superiority of the selected models against alternatives. After this, having estimated the selected ARDL models (14-20), tests of possible cointegrating relationship among the series were conducted. The results obtained are shown in table 7 (in Appendix II). All the tests were conducted at 5 percent level of significance. As evident from the table, in each case, the computed ( $F$-statistics) is greater than upper bond values at 5 percent level of significance. Thus, the null hypotheses of no cointegrating relationship among the variables of interest were rejected.

Sequel to the establishment of the existence of cointegration relationship among the series, the long- and short-run elasticities coefficients associated with the ARDL models (14-20) were estimated. However, while the results of the estimated long-run parameters of the selected models are presented in table 8 (in Appendix II), the study did not find any consistent estimated short-run dynamics associated with the long-run parameters obtained from the models. As such, they are not presented here in order to conserve space. It is worth noting that, for the purpose of comprehension, columns (I) and (II) of table 8 depict the long-run estimates of the impact of income inequality on economic growth (i.e. models 14 and 15), while columns (III-VII) of the table present the long-run elasticities coefficients of the five distinct transmission channels (i.e. models 16-20), through which inequality impacts growth. 


\subsection{Long-Run Estimates of the Impacts of Income Inequality on Economic Growth}

Regarding the impacts of income inequality on economic growth, as can be seen from column (I) of table 8, the parameter estimate of Gini index has expected sign and is statistically significant. Precisely, in the long run, holding other things constant, a one percentage point increase in inequality in the distribution income will bring about 2.7023664 decrease in economic growth. In specification 2 (model 15), as previously stated, in an attempt to conduct the estimation of econometric model (14), it is likely that income inequality specified in the model captures the impact of poverty on growth. Thus, the study controlled for poverty incidence in a separate regression. Hence, in model (15), a measure for poverty incidence proxied by headcount ratio is incorporated as an additional term in order to capture the true growth impacts of income inequality. From the estimated model 15 (specification 2), an insight from the estimated long-run parameters obtained suggests that as the level of poverty incidence persists unabated, undoubtedly, the impact of inequality in the distribution income on long-run growth worsens in Nigeria. As can be observed from column (II) of table 8, the elasticities coefficients of both poverty incidence proxied by headcount ratio and Gini index are negative and highly statistically significant. Intrinsically, ceteris paribus, a one percentage point increase in both poverty incidence and Gini coefficient respectively will bring about 5.047328 and 6.93779 decrease in the long-run economic growth. Similar findings were also observed in Shin (2012), Herzer and Vollmer (2012), Wahiba and El Weriemmi (2013), Fawaz, Rahnama, and Valcarcel (2014), Cingano (2014), Ostry, Berg, and Tsangarides (2014), Darma and Ali (2014), Bagchi and Svejnar (2015), Njindan Iyke and Ho (2017), and Lahouij (2017).

With regards to the control variables, as evident in both columns (I) and (II) of table 8, the growth rate of labour force and human capital accumulation significantly enhanced the growth rate of income per capita as anticipated. Their estimated parameters have expected signs and are highly statistically significant, suggesting that labour force equipped with proper education and training, balanced health facilities and assisted by necessary tools and implements, is a vital determinant of long-run growth in Nigeria. This result is consistent with economic theory and validates the empirical findings of Raleva (2014) for the case of Bulgaria, and Hundie (2014) for the case of Ethiopia. More so, as depicted in both columns (I) and (II) of table 8, the elasticity coefficient of the growth rate of population is positive but statistically insignificant, signifying that a carefully planned population growth strategy combined with institutional and policy changes will be advantageous to long-run growth in Nigeria. In the same way, vis-à-vis the impact of financial deepening on growth, an insight from the results obtained suggest that while the financial system has grown enormously in size and structure in Nigeria, however, this has not been translated to the provision of credits and loans, in particular, to the real sector of the economy. As can be seen from columns (I) and (II) of table 8 , the elasticities coefficient of financial deepening is positive but statistically insignificant. Similar findings were also observed in Igwe, Edeh, and Ukpere (2013).

In addition, on the impact of trade openness (proxy as trade share in GDP) on growth, as can be seen from the results depicted in columns (I) and (II) of table 8, the elasticity coefficients have a significant and negative impact on long-run growth in Nigeria. As shown in the table, premised on the estimated parameters, keeping all else constant, for a one-percentage point increase in trade openness, as evident in models 14 and 15 respectively, 7.023664 and 8.070993 decline are induced in the long-run economic growth. This evidence of negative impact of trade openness on growth indubitably depicts the Nigerian economy where the volume of import is skewed towards semi processed goods deviously packed as raw materials and export is dominated by crude oil, the price and quantity of which is determined on the global market and has little or no connection to economic reality. Similar results were obtained in Olufemi (2004). As well, in line with the theoretical explanations of convergence hypothesis, the coefficient of income per worker is positive and statistically significant as anticipated. As can be observed, the parameter estimates of income per worker has expected sign and is statistically significant. This result lends credence to the empirical findings of Chletsos and Fatouros (2016).

\subsection{Long-Run Estimates of the Transmission Channels of Income Inequality to Economic Growth}

With respect to the channels through which inequality impacts growth, in order to provide an intuitive insight to the classical economists and modern expositions predictions of some of the distinct transmission channels, the long-run parameters associated with the models (16-20) were estimated. The results obtained are shown in table 8 . As can be seen from the table, columns (III-VII) respectively depicts the investment, fertility rate, human capital accumulation, relative redistribution and property rights protection channels. In all the five specifications, as depicted in the table, the elasticity coefficients of Gini index have the expected signs and are highly statistically significant. As evident from the table, all other things being equal, in the long run, a one percentage point increase in income inequality will bring about 0.654663 and 0.714514 increases in fertility rate and relative redistribution respectively. By contrast, as 
evident in models 16, 18 and 20, for a one percentage point increase in income inequality, 0.015552, 0.652238 and 0.181760 declines are induced in investment rate, human capital accumulation, and property rights protection respectively. In essence, premised on the estimated parameters, an upsurge in income inequality increases fertility rate and relative redistribution, but lessens investment rate, human capital accumulation, and property rights protection, which may in turn impede long-run growth in Nigeria. Hence, these findings not only corroborate the theoretical predictions of modern perspective exposition, which underscored the potential adverse impacts of income inequality on economic growth, but also invalidate the classical and neoclassical economists' predictions.

\subsection{Stability and Diagnostic Tests}

Following the long- and short-run estimations of the elasticities coefficients associated with the ARDL models (14-20), in order to check the robustness of the estimated regression results, the study carried out different post-estimation diagnostic tests. The results of the respective diagnostic test, in each case, are depicted in table 9 (in Appendix II). As can be observed, the residuals of the models are serially uncorrelated, normally distributed and homoscedastic. Indeed, the estimated results are devoid of econometric problems of auto-correlation, mis-specification and heteroskedasticity. In addition, since the ARDL models (14-20) were estimated by simple least squares, all of the views and procedures available to equation objects estimated by least squares are also available for the ARDL models. As such, the $R^{2}$, Adjusted $R^{2}$, F-statistic and Durbin-Watson statistic in each case for the selected ARDL models are depicted in the lower segment of the table 8 . All the tests revealed that the models have the desirable BLUE properties. As can be seen from the lower segment of the table 8, the F-statistic which measures the overall significance of the estimated models were statistically significant, suggesting that models are fit and suitable for the empirical estimations. Also, as can be observed the explanatory power (the $R^{2}$ ) of the models are high.

Moreover, the Adjusted $R^{2}$ which measures the share of variation jointly explained by the explanatory variables after the effects of insignificant regressors have been removed are also high. As well, the Durbin-Watson statistic which is used to test for autocorrelation of residuals in the models, particularly, the first order autocorrelation displayed the absence of serial autocorrelation. Finally, as suggested by Brown, Durbin and Evans (1975), the cumulative sum of recursive residuals (CUSUM) and the cumulative sum of recursive residual squares (CUSUMSQ) were also plotted to determine if the models were stable. A graphical presentation of this test for the selected ARDL models is depicted in figures 9-22 (in Appendix I). As can be seen from the graphs, the results evidently indicate the absence of instability of the estimated coefficients because the plot of the CUSUM and CUSUMSQ statistic(s) is within the confines of the 5 percent critical bounds.

\section{Conclusion}

The debate on whether income inequality promotes, restricts, or is independent of economic growth has been widely studied and discussed in development economics discourse. However, a careful reading of this extensive extant and burgeoning literature suggests that, other than the ambivalent nature and the fact that the bulk of these studies relied heavily on cross-section/-country/panel econometric analysis, empirical studies examining the nexus in the context of less developed economies, particularly, African countries, has received less attention, as most of the extant studies predominantly focused on developed economies. This current study, thus, attempts to examine the impact of inequality on growth in Nigeria spanning between the period 1970 and 2018. It also examined the theoretical predictions of the classical economists and modern expositions predictions of some of the distinct transmission channels through which inequality impacts growth. Time series econometrics were applied. The results obtained consistently revealed that inequality hurts long-run growth in Nigeria. Also, the results obtained revealed that inequality in income increases relative redistribution and fertility, but lessens investment, gross enrollment ratio, and property rights protection in Nigeria, which may in turn impede growth. Hence, these findings not only corroborate the theoretical predictions of modern perspective exposition, which underscored the potential adverse impacts of income inequality on economic growth, but also invalidate the classical and neoclassical economists' predictions.

\section{References}

Abubakar J. F. (2017). Economic growth and income inequality: The case of Brazil. Doctoral dissertation, American University of Nigeria, Department of Economics.

Acemoglu, D., \& Robinson, J. A. (2008). Persistence of power, elites, and institutions. American Economic Review, 98(1), 267-93.

Adawo, M. A. (2011). Has education (human capital) contributed to the economic growth of Nigeria?. Journal of Economics and International Finance, 3(1), 46-58. 
Adigun, G., Awoyemi, T., \& Omonona, B. T. (2011). Estimating economic growth and inequality elasticities of poverty in rural Nigeria. Estimating Economic Growth and Inequality Elasticities of Poverty in Rural Nigeria, 4(1), 25-35.

Aghion, P., \& Bolton, P. (1992). Distribution and growth in models of imperfect capital markets. European Economic Review, 36(2-3), 603-611.

Aghion, P., \& Bolton, P. (1997). A theory of trickle-down growth and development. The Review of Economic Studies, 64(2), 151-172.

Aghion, P., Caroli, E., \& Garcia-Penalosa, C. (1999). Inequality and economic growth: the perspective of the new growth theories. Journal of Economic Literature, 37(4), 1615-1660.

Agyemang, E. (2014). Economic growth, income inequality and poverty reduction: a regional comparative analysis. Doctoral dissertation, Lethbridge, Alta.: University of Lethbridge, Dept. of Economics.

Aigbokhan, B. E. (2008). Growth, inequality and poverty in Nigeria. Prepared for United Nations Economic Commission for Africa (UNECA). Addis Ababa, Ethiopia.

Aigbokhan, B. E. (2017). The Price of Inequality in Nigeria. In Presidential Address Delivered at the 58th Annual Conference of the Nigerian Economic Society held at Nicon Luxury Hotel, Abuja (pp. 26-28).

Akinbobola, T. O., \& Saibu, M. O. O. (2004). Income inequality, unemployment, and poverty in Nigeria: a vector autoregressive approach. The Journal of Policy Reform, 7(3), 175-183.

Akpoilih, R., \& Farayibi, A. (2012). Economic Growth and Inequality in Nigeria: Magnitudes and Challenges. University of Ibadan.

Alesina, A., \& Perotti, R. (1996). Income distribution, political instability, and investment. European Economic Review, 40(6), 1203-1228.

Alesina, A., \& Perotti, R., (1993). Income distribution, political instability, and investment. NBER Working Paper No. 4486.

Alesina, A., \& Rodrik, D. (1994). Distributive politics and economic growth. The Quarterly Journal of Economics, 109(2), 465-490.

Amendola, A., Easaw, J., \& Savoia, A. (2013). Inequality in developing economies: the role of institutional development. Public Choice, 155(1-2), 43-60.

Amir, H., Khan, M., \& Bilal, K. (2015). Impact of educated labor force on Economic growth of Pakistan: A human capital perspective. European Online Journal of Natural and Social Sciences, 4(4), pp-814.

Andreano, M. S., Laureti, L., \& Postiglione, P. (2013). Economic growth in MENA countries: Is there convergence of per-capita GDPs?. Journal of Policy Modeling, 35(4), 669-683.

Assa, J. (2012). Inequality and growth re-examined. Technology and Investment, 3(01), 1.

Awe, A., \& Ojo, R. (2012). Determinants of income distribution in the Nigeria economy: 1977-2005. International Business and Management, 5(1), 126-137.

Bagchi, S., \& Svejnar, J. (2015). Does wealth inequality matter for growth? The effect of billionaire wealth, income distribution, and poverty. Journal of Comparative Economics, 43(3), 505-530.

Balisacan, A. M., \& Fuwa, N. (2003). Growth, inequality and politics revisited: A developing-country case. Economics Letters, 79(1), 53-58.

Banerjee, A. (2004). Inequality and investment. Massachusetts Institute of Technology. Cambridge, Massachusetts.

Banerjee, A. V., \& Duflo, E. (2003). Inequality and growth: What can the data say?. Journal of Economic Growth, 8(3), 267-299.

Banerjee, A. V., \& Newman, A. F. (1993). Occupational choice and the process of development. Journal of Political Economy, 101(2), 274-298.

Banerjee, A., Dolado, J., \& Mestre, R. (1998). Error-correction mechanism tests for cointegration in a single-equation framework. Journal of Time Series Analysis, 19(3), 267-283.

Barro, R. J. (2000). Inequality and Growth in a Panel of Countries. Journal of Economic Growth, 5(1), 5-32. 
Barro, R. J. (2008). Inequality and growth revisited (No. 11). ADB Working paper series on regional economic integration.

Barro, R., \& Sala-i-Martin, X. (1997). Technology diffusion, convergence, and growth. Journal of Economic Growth, $2,1-26$.

Beck, N., \& Katz, J. N. (1996). Nuisance vs. substance: Specifying and estimating time-series-cross-section models. Political Analysis, 6, 1-36.

Becker, G. S., \& Barro, R. J. (1988). A reformulation of the economic theory of fertility. The Quarterly Journal of Economics, 103(1), 1-25.

Benabou, R. (2002). Tax and education policy in a heterogeneous-agent economy: What levels of redistribution maximize growth and efficiency?. Econometrica, 70(2), 481-517.

Benhabib, J., \& Spiegel, M. M. (1994). The role of human capital in economic development evidence from aggregate cross-country data. Journal of Monetary economics, 34(2), 143-173.

Bernstein, J. (2013). The impact of inequality on growth. Center for American Progress, Washington.

Besley, T., \& Ghatak, M. (2010). Property rights and economic development. In Handbook of development economics (Vol. 5, pp. 4525-4595). Elsevier.

Birdsall, N., \& Londoño, J. L. (1997). Asset inequality matters: an assessment of the World Bank's approach to poverty reduction. The American Economic Review, 87(2), 32-37.

Birdsall, N., Ross, D., \& Sabot, R. (1995). Inequality and growth reconsidered: lessons from East Asia. The World Bank Economic Review, 9(3), 477-508.

Bloom, D. E., Canning, D., \& Malaney, P. N. (1999). Demographic change and economic growth in Asia. CID.

Brown, R. L., Durbin, J., \& Evans, J. M. (1975). Techniques for Testing the Constancy of Regression Relationships Over Time. Journal of the Royal Statistical Society, Series B, 37, 149-192.

Castelló, A., \& Doménech, R. (2002). Human capital inequality and economic growth: some new evidence. The Economic Journal, 112(478), C187-C200.

Castelló-Climent, A. (2010). Inequality and growth in advanced economies: an empirical investigation. The Journal of Economic Inequality, 8(3), 293-321.

CBN. (2019). Central Bank of Nigeria Statistical Bulletin. Retrieved from https://www.cbn.gov.ng

Chambers, D., \& Dhongde, S. (2011). A Non-Parametric Measure of Poverty Elasticity. Review of Income and Wealth, 57(4), 683-703.

Chambers, D., \& Krause, A. (2010). Is the relationship between inequality and growth affected by physical and human capital accumulation?. The Journal of Economic Inequality, 8(2), 153-172.

Chang, J. Y., \& Ram, R. (2000). Level of development, rate of economic growth, and income inequality. Economic Development and Cultural Change, 48(4), 787-799.

Charles-Coll, J., Granados, E. M., \& De la Garza Ramos, M. I. (2015). Income Inequality, Fertility, Human Capital Accumulation and Economic Growth in Mexico. Research in World Economy, 6(1), 172-183.

Cheema, A. R., \& Rehman, A. (2014). Existence of Kuznets Curve in Pakistan: Evidence From HIES Data Set, 1993 To 2011. International Journal of Business and Social Science, 5(5).

Chen, B. L. (2003). An inverted-U relationship between inequality and long-run growth. Economics Letters, 78(2), 205-212.

Chen, W. (2018). The effects of income inequality on economic growth: evidence from China (Doctoral dissertation, University of Bath).

Chletsos, M., \& Fatouros, N. (2016). Does income inequality matter for economic growth? An empirical investigation.

Cincotta, R. P., \& Engelman, R. (1997). Economics and rapid change: the influence of population growth.

Cingano, F. (2014). Trends in income inequality and its impact on economic growth.

Clarke, G. R. (1995). More evidence on income distribution and growth. Journal of development Economics, 47(2), 403-427. 
Dahan, M., \& Tsiddon, D. (1998). Demographic transition, income distribution, and economic growth. Journal of Economic growth, 3(1), 29-52.

Dahlby, B., \& Ferede, E. (2013). Income inequality, redistribution and economic growth. University of Calgary. The School of Public Policy Publications, 6(25).

Darma, N. A., \& Ali, M. (2014). An Empirical Analysis of the Effect of Income Inequality on Economic Growth in West Africa. Journal of Empirical Economics, 3(4), 221-231.

Dauda, R. O. S. (2004). Poverty, Inequality and Socio-Economic Development Policies in Nigeria. In Fakiyesi \& Akano (Eds.), Issues in Money, Finance and Economic Management in Nigeria: Essays in Honour of Obasanmi Olakanpo. Department of Economics, University of Lagos.

De Dominicis, L., Florax, R. J., \& De Groot, H. L. (2008). A meta-analysis on the relationship between income inequality and economic growth. Scottish Journal of Political Economy, 55(5), 654-682.

De La Croix, D., \& Doepke, M. (2003). Inequality and growth: why differential fertility matters. American Economic Review, 93(4), 1091-1113.

Deaton, A. (2003). Health, inequality, and economic development. Journal of Economic Literature, 41(1), 113-158.

Deaton, A. S., \& Paxson, C. (2004). Mortality, income, and income inequality over time in Britain and the United States. In Perspectives on the Economics of Aging (pp. 247-286). University of Chicago Press.

Deininger, K., \& Olinto, P. (1999). Asset distribution, inequality, and growth. The World Bank.

Deininger, K., \& Olinto, P. (2000). Asset distribution, inequality, and growth, The World Bank Development Research Group. Working Paper No. 2375.

Deininger, K., \& Squire, L. (1996). A new data set measuring income inequality. The World Bank Economic Review, $10(3), 565-591$.

Deininger, K., \& Squire, L. (1998). New ways of looking at old issues: inequality and growth. Journal of Development Economics, 57(2), 259-287.

Delbianco, F., Dabús, C., \& Caraballo, M. Á. (2014). Income inequality and economic growth: New evidence from Latin America. Cuadernos de Economía, 33(63), 381-398.

Denton, F. T., \& Spencer, B. G. (1997). Population, labour force and long-term economic growth. McMaster University, Faculty of Social Sciences, Program for Research on the Independence and Economic Security of the Older Population.

Devarajan, S., Swaroop, V., \& Zou, H. F. (1996). The composition of public expenditure and economic growth. Journal of Monetary Economics, 37(2), 313-344.

Easterly, W. (2007). Inequality does cause underdevelopment: Insights from a new instrument. Journal of Development Economics, 84(2), 755-776.

Ehrhart, C. (2009). The effects of inequality on growth: a survey of the theoretical and empirical literature. ECINEQ WP, 107.

El-Wassal, K. A. (2012). Foreign direct investment and economic growth in Arab countries (1970-2008): An inquiry into determinants of growth benefits. Journal of Economic Development, 37(4), 79.

Engle, R. F., \& Granger, C. W. (1987). Co-integration and error correction: representation, estimation, and testing. Econometrica: Journal of the Econometric Society, 251-276.

Er, P. H., Tugcu, C. T., \& Coban, O. (2014). Investigating the link between savings, inflation and economic growth: an ARDL analysis for the case of Turkey. Journal of Economics Finance and Accounting, 1(2), 81-90.

Ewubare, D. B., \& Okpani, A. O. (2018). Poverty and income inequality in Nigeria (1980-2017). International Journal of Advanced Studies in Ecology, Development and Sustainability.

Fallah, B. N., \& Partridge, M. (2007). The elusive inequality-economic growth relationship: are there differences between cities and the countryside?. The Annals of Regional Science, 41(2), 375-400.

Fawaz, F., Rahnama, M., \& Valcarcel, V. J. (2014). A refinement of the relationship between economic growth and income inequality. Applied Economics, 46(27), 3351-3361. 
Forbes, K. J. (2000). A reassessment of the relationship between inequality and growth. American Economic Review, 90(4), 869-887.

Furman, J., \& Stiglitz, J. E. (1998, August). Economic consequences of income inequality. In Income Inequality: Issues and Policy Options-Proceedings of a Symposium Sponsored by the Federal Reserve Bank of Kansas City (p. 255).

Galor, O. (2009). Inequality and economic development: An overview (No. 2009-3). Working Paper.

Galor, O., \& Zang, H. (1997). Fertility, income distribution, and economic growth: theory and cross-country evidence. Japan and the World Economy, 9(2), 197-229.

Galor, O., \& Zeira, J. (1989). Income distribution and macroeconomics. Technical Report 25, Department of Economics, Brown University.

Galor, O., \& Zeira, J. (1993). Income distribution and macroeconomics. The Review of Economic Studies, 60(1), 35-52.

Ghildiyal, V., Pokhriyal, A. K., \& Mohan, A. (2015). Impact of financial deepening on economic growth in Indian perspective: ARDL bound testing approach to cointegration. Asian Development Policy Review, 3(3), 49-60.

Gradstein, M. (2007). Inequality, democracy and the protection of property rights. The Economic Journal, 117(516), 252-269.

Granger, C. W. (1988). Some recent development in a concept of causality. Journal of Econometrics, 39(1-2), 199-211.

Gregory, A. W., \& Hansen, B. E. (1996). Practitioners' corner: tests for cointegration in models with regime and trend shifts. Oxford bulletin of Economics and Statistics, 58(3), 555-560.

Grijalva, D. F. (2011). Inequality and Economic Growth: Bridging the Short-run and the Long-run.

Gründler, K., \& Scheuermeyer, P. (2015). Income inequality, economic growth, and the effect of redistribution (No. 95). Würzburg Economic Papers.

Gwartney, J., Lawson, R., Walker, M., Block, W., \& Easton, S. T. (2019). Economic Freedom of the World Index $(\mathrm{EFW})$.

Gylfason, T., \& Zoega, G. (2003). Inequality and economic growth: Do natural resources matter?. Inequality and Growth: Theory and Policy Implications, 1, 255.

Halter, D., Oechslin, M., \& Zweimüller, J. (2014). Inequality and growth: the neglected time dimension. Journal of Economic Growth, 19(1), 81-104.

Herzer, D., \& Vollmer, S. (2012). Inequality and growth: evidence from panel cointegration. The Journal of Economic Inequality, 10(4), 489-503.

Ho, S. Y., \& Odhiambo, N. M. (2011). Finance and poverty reduction in China: an empirical investigation. International Business \& Economics Research Journal (IBER), 10(8), 103-114.

Huang, H. C. R. (2004). A flexible nonlinear inference to the Kuznets hypothesis. Economics Letters, 84(2), 289-296.

Hundie, S. K. (2014). Savings, investment and economic growth in Ethiopia: Evidence from ARDL approach to co-integration and TYDL Granger-causality tests. Journal of Economics and International Finance, 6(10), 232-248.

Igwe, A., Edeh, C. E., \& Ukpere, W. I. (2013). Financial Deepening and Economic Growth in Nigeria (1981-2012): A Managerial Economic Perspective. Risk Governance \& Control: Financial Markets and Institutions, 120.

Iradian, M. G. (2005). Inequality, Poverty, and Growth: Cross-Country Evidence (EPub) (No. 5-28). International Monetary Fund.

Isere, V. O., Ibrahim, S. A., \& Agu, C. O. (2010). The impact of income inequality on the Nigerian economy. Multidisciplinary Journal of Research Development 15(2), 1-6.

Islam, M. (2017). Income Inequality and Economic Growth Nexus in Japan: A Multivariate Analysis The Ritsumeikan economic review: the bi-monthly journal of Ritsumeikan University, 65(4), 439-456.

Islam, S. (1995). The human development index and per capita GDP. Applied Economics Letters, 2(5), $166-167$. 
Jalil, A. (2012). Modeling income inequality and openness in the framework of Kuznets curve: New evidence from China. Economic Modelling, 29(2), 309-315.

Jalilian, H., \& Kirkpatrick, C. (2005). Does financial development contribute to poverty reduction?. Journal of Development Studies, 41(4), 636-656.

Johansen, S. (1988). Statistical analysis of cointegration vectors. Journal of Economic Dynamics and Control, 12(2-3), 231-254.

Joshi, R. (2018). Assessing the Impact of Income Inequality on Economic Growth: For a Cross Section of Indian States. The Indian Economic Journal, 65(1-4), 1-26.

Kaldor, N. (1955). Alternative theories of distribution. The Review of Economic Studies, 23(2), 83-100.

Kandek, B., \& Kajling, V. (2017). Income Inequality and Economic Growth: What relation does regional income inequality have with local economic growth in US Metropolitan Areas?

Kar, M., Agir, H., \& Peker, O. (2011). Financial development and poverty reduction in Turkey. Department of Economics, Adana, Çukurova University, Turkey.

Kazbekova, Z. (2018). Impact of the demographic dividend on economic growth. Population and Economics, 2, 85.

Keefer, P., \& Knack, S. F. (1995). Polarization, Property Rights, and the Links between Inequality and Growth. Center for Institutional Reform and the Informal Sector, University of Maryland at College Park.

Keho, Y. (2017). The impact of trade openness on economic growth: The case of Cote d'Ivoire. Cogent Economics \& Finance, 5(1), 1332820.

Kennedy, T., Smyth, R., Valadkhani, A., \& Chen, G. (2017). Does income inequality hinder economic growth? New evidence using Australian taxation statistics. Economic Modelling, 65, 119-128.

Kirkpatrick, C., Sirageldin, I., \& Aftab, K. (2000). Financial Development, Economic Growth, and Poverty Reduction [with Comments]. The Pakistan Development Review, 363-388.

Klasen, S., \& Lawson, D. (2007). The impact of population growth on economic growth and poverty reduction in Uganda (No. 133). Diskussionsbeiträge.

Knell, M. (1999). Social comparisons, inequality, and growth. Journal of Institutional and Theoretical Economics (JITE)/Zeitschrift für die gesamte Staatswissenschaft, 664-695.

Knowles, S. (2005). Inequality and economic growth: the empirical relationship reconsidered in the light of comparable data. The Journal of Development Studies, 41(1), 135-159.

Kolawole, B. O., Omobitan, O. A., \& Yaqub, J. O. (2015). Poverty, inequality and rising growth in Nigeria: Further empirical evidence. International Journal of Economics and Finance, 7(2), 51-62.

Kremers, J. J., Ericsson, N. R., \& Dolado, J. J. (1992). The power of cointegration tests. Oxford Bulletin of Economics and Statistics, 54(3), 325-348.

Kuznets, S. (1955). Economic growth and income inequality. The American Economic Review, 1-28.

Kuznets, S. (1963). Quantitative aspects of the economic growth of nations: VIII. Distribution of income by size. Economic Development and Cultural Change, 11(2, Part 2), 1-80.

Lahouij, H. (2017). The Effects of Income inequality on Economic Growth Evidence from MENA Countries. Awards for Excellence in Student Research and Creative Activity - Documents 4.

Lai, P. L., Tan, K. K. Y., Ong, H. W., \& Lee, V. W. T. (2015). An empirical study on trade openness and income inequality in Latin America incorporating with FDI inflows, GDP growth and inflation (Doctoral dissertation, UTAR).

Leoni, T., \& Pollan, W. (2003). The impact of inequality on economic growth (No. 211). WIFO Working Papers.

Levine, R. (1997). Financial development and economic growth: views and agenda. Journal of Economic Literature, $35(2), 688$.

Li, H., \& Zhang, J. (2007). Do high birth rates hamper economic growth?. The Review of Economics and Statistics, 89(1), 110-117.

Li, H., \& Zou, H. F. (1998). Income inequality is not harmful for growth: theory and evidence. Review of Development Economics, 2(3), 318-334. 
Liew, V. K-S. (2004). Which Lag Length Selection Criteria Should We Employ?. Economics Bulletin, 3(33), 1-9.

Lim, G. C., \& McNelis, P. D. (2014). Income inequality, trade and financial openness.

Lin, S. C., \& Weng, H. W. (2006). A semi-parametric partially linear investigation of the Kuznets' hypothesis. Journal of Comparative Economics, 34(3), 634-647.

Lin, S. C., Huang, H. C., Kim, D. H., \& Yeh, C. C. (2009). Nonlinearity between inequality and growth. Studies in Nonlinear Dynamics \& Econometrics, 13(2).

Lin, Y. C., \& Yeh, C. C. (2009). Joint determinations of inequality and growth. Economics Letters, 103(3), 163-166.

Loayza, N., \& Ranciere, R. (2004). Financial development, financial fragility, and growth. The World Bank.

Locke, A. (2013). Property rights and development briefing: Property rights and economic growth. Overseas Development Institute.

Luebker, M. (2014). Income inequality, redistribution, and poverty: Contrasting rational choice and behavioral perspectives. Review of Income and Wealth, 60(1), 133-154.

Luintel, K. B., \& Khan, M. (1999). A quantitative reassessment of the finance-growth nexus: evidence from a multivariate VAR. Journal of Development Economics, 60(2), 381-405.

Macan, V. J., \& Deluna Jr, R. (2013). Relationship of Income Inequality and Labor Productivity on Fertility in the Philippines: 1985-2009.

Madsena, J. B., Islamb, M. R., \& Doucouliagosc, H. (2016). Inequality, financial development and economic growth in the OECD.

Majeed, M. T. (2010). Inequality, trade openness and economic growth in Asia.

Majeed, M. T. (2016a). Economic Growth and Income Inequality Nexus: An Empirical Analysis for Pakistan. Quaid-i-Azam University, Islamabad.

Majeed, M. T. (2016b). Economic growth, inequality and trade in developing countries. International Journal of Development Issues, 15(3), 240-253.

Malinen, T. (2013). Inequality and growth: Another look with a new measure and method. Journal of International development, 25(1), 122-138.

Mankiw, N. G., Romer, D., \& Weil, D. N. (1992). A contribution to the empirics of economic growth. The quarterly journal of economics, 107(2), 407-437.

Mayah, E., Mariotti, C., Mere, C. E., \& Odo, C. O. (2017). Inequality in Nigeria: Exploring the drivers.

Mbarek, M. B., Saidi, K., \& Rahman, M. M. (2018). Renewable and non-renewable energy consumption, environmental degradation and economic growth in Tunisia. Quality \& Quantity, 52(3), 1105-1119.

McKinnon, R. I. (1973). Money and capital in economic development. Brookings Institution Press.

McKinnon, R. I. (2010). Money and capital in economic development. Brookings Institution Press.

Mo, P. H. (2000). Income inequality and economic growth. Kyklos, 53(3), 293-315.

Mody, M. A., \& Aiyar, M. S. (2011). The demographic dividend: Evidence from the Indian states (No. 11-38). International Monetary Fund.

Naguib, C. (2017). The Relationship between Inequality and Growth: Evidence from new data. Swiss Journal of Economics and Statistics, 153(3), 183-225.

Narayan, P. K. (2005). The saving and investment nexus for China: evidence from cointegration tests. Applied Economics, 37(17), 1979-1990.

National Bureau of Statistics, NBS. (2018).The Nigerian Statistical Fact Sheet on Economic \& Social Development. Abuja: NBS.

Nindi, A. G., \& Odhiambo, N. M. (2015). Poverty and Economic Growth in Swaziland: An Empirical Investigation. Managing Global Transitions: International Research Journal, 13(1).

Njindan Iyke, B., \& Ho, S. Y. (2017). Income inequality and growth: new insights from Italy. Deakin University, University of South Africa.

Noh, Y. H., \& Yoo, K. (2008). Internet, inequality and growth. Journal of Policy Modeling, 30(6), 1005-1016. 
Nwosa, P. I. (2019). Income Inequality and Economic Growth in Nigeria: Implication for Economic Development. Acta Universitatis Danubius. Economica, 15(1).

Oded, G. (2011). Inequality, human capital formation, and the process of development. In Handbook of the Economics of Education (Vol. 4, pp. 441-493). Elsevier.

Odedokun, M. O., \& Round, J. I. (2001). Determinants of income inequality and its effects on economic growth: evidence from African countries (No. 2001/103). WIDER Discussion Papers//World Institute for Development Economics (UNU-WIDER).

Odhiambo, N. M. (2009). Financial deepening and poverty reduction in Zambia: an empirical investigation. International Journal of Social Economics, 37(1), 41-53.

Odusanya, I. A., \& Agboola, B. (2017). Income, Income Inequality and Health: Evidence from Nigeria. Izvestiya, (4), 345-361.

Odusola, A., Mugisha, F., Workie, Y., \& Reeves, W. (2017). Income Inequality and Population Growth in Africa. Income Inequality Trends in Sub-Saharan Africa: Divergence, Determinants and Consequences (2017).

Ogbeide, E. N. O., \& Agu, D. O. (2015). Poverty and Income Inequality in Nigeria: Any Causality?. Asian Economic and Financial Review, 5(3), 439.

Oloufade, D. (2012). Trade Openness, Conflict Risk and Income Inequality. Conflict Risk and Income Inequality (August 24, 2012).

Olufemi, S. M. (2004). Trade openness and economic growth in Nigeria: Further evidence on the causality issue. South African Journal of Economic and Management Sciences, 7(2), 299-315.

Onaran, Ö., \& Oyvat, C. (2015). The political economy of inequality, redistribution and boom-bust cycles in Turkey.

Ostry, M. J. D., Berg, M. A., \& Tsangarides, M. C. G. (2014). Redistribution, inequality, and growth. International Monetary Fund.

Pagano, P. (2004). An empirical investigation of the relationship between inequality and growth (Vol. 536). Banca d'Italia.

Panizza, U. (2002). Income inequality and economic growth: evidence from American data. Journal of Economic Growth, 7(1), 25-41.

Partridge, M. D. (1997). Is inequality harmful for growth? Comment. The American Economic Review, 87(5), 1019-1032.

Patrick, H. T. (1966). Financial development and economic growth in underdeveloped countries. Economic Development and Cultural Change, 14(2), 174-189.

Perotti, R. (1994). Income distribution and investment. European Economic Review, 38(3-4), 827-835.

Perotti, R. (1996). Growth, income distribution, and democracy: What the data say. Journal of Economic growth, l(2), 149-187.

Persson, T., \& Tabellini, G. (1994). Is inequality harmful for growth?. The American Economic Review, 600-621.

Pesaran, M. H., \& Shin, Y. (1995), 'Autoregressive Distributed Lag Modeling Approach to Cointegration Analysis'. DAE Working Paper Series, No. 9514, Department of Economics, University of Cambridge.

Pesaran, M. H., \& Shin, Y. (1998), 'An Autoregressive Distributed lag Modeling Approach to Cointegration Analysis'. In S. Storm (Ed.), Econometrics and Economic Theory in the 20th Century: The Ragnar Frisch Centennial Symposium. Cambridge: Cambridge University Press

Pesaran, M. H., \& Shin, Y. (1998). An autoregressive distributed-lag modelling approach to cointegration analysis. Econometric Society Monographs, 31, 371-413.

Pesaran, M. H., Shin, Y., \& Smith, R. J. (2001). Bounds testing approaches to the analysis of level relationships. Journal of Applied Econometrics, 16(3), 289-326.

Pesaran, M. H., Shin, Y., \& Smith, R. P. (1999). Pooled mean group estimation of dynamic heterogeneous panels. Journal of the American Statistical Association, 94(446), 621-634.

Piketty, T. (1997). The dynamics of the wealth distribution and the interest rate with credit rationing. The Review of Economic Studies, 64(2), 173-189. 
Quartey, P. (2005). Financial sector development, savings mobilization and poverty reduction in Ghana. UNU-WIDER 2005, Research Paper No. 2005/71, United Nations University, Helsinki, Finland.

Raleva, S. (2014). Impact of labour on economic growth in Bulgaria (1991-2013). Economic Alternatives, 3, 5-14.

Ram, R. (1984). Population increase, economic growth, educational inequality, and income distribution: Some recent evidence. Journal of Development Economics, 14(3), 419-428.

Ravallion, M. (1997). Can high-inequality developing countries escape absolute poverty?. Economics Letters, 56(1), 51-57.

Ravallion, M. (1998). The Emerging New Form of Social Protection in 21st Century China. World Bank, Washington, DC.

Ravallion, M. (2017). Poverty comparisons. Routledge.

Ray, D., \& Linden, M. (2018). Health, inequality and income: a global study using simultaneous model. Journal of Economic Structures, 7(1), 22.

Rebeira, M., Grootendorst, P., Coyte, P. C., \& Aguirregabiria, V. (2017). Does rising income inequality affect mortality rates in advanced economies?. Economics: The Open-Access, Open-Assessment E-Journal, 11(2017-16), 1-23.

Rehman, H. U., Khan, S., \& Ahmed, I. (2008). Income distribution, growth and financial development: A cross countries analysis. Pakistan Economic and Social Review, 1-16.

Rehme, G. (2002). Education, economic growth and personal income inequality across (rich) countries.

Rivera-Batiz, L. A., \& Romer, P. M. (1991). Economic integration and endogenous growth. The Quarterly Journal of Economics, 106(2), 531-555.

Romer, P. M. (1989). Human capital and growth: theory and evidence (No. w3173). National Bureau of Economic Research.

Romer, P. M. (1990). Endogenous technological change. Journal of Political Economy, 98(5), 71-102.

Rostow, W. W. (1959). The stages of economic growth. The Economic History Review, 12(1), 1-16.

Samantaraya, A., \& Patra, S. K. (2014). Determinants of household savings in India: An empirical analysis using ARDL approach. Economics Research International, 2014.

Schultz, T. P. (2008). Fertility in developing countries (pp. 2097-2101). Palgrave Macmillan UK.

Shaw, E. S. (1973). Financial deepening m economic development. Oxford University Press, New York.

Shin, I. (2008). Income inequality and economic growth.

Shin, I. (2012). Income inequality and economic growth. Economic Modelling, 29(5), 2049-2057.

Siddiqui, D. A., \& Ahmed, Q. M. (2009). The causal relationship between institutions and economic growth: An empirical investigation for Pakistan economy. University of Karachi.

Sieng, L. W., \& Yussof, I. (2014). Human capital accumulation and economic growth in Malaysia-Investigating the long run nexus. Jurnal Ekonomi Malaysia, 48(1), 155-165.

Solt, F. (2016). The standardized world income inequality database. Social Science Quarterly, 97(5), 1267-1281.

Sonin, K. (1999). Inequality, property rights protection, and economic growth in transition economies: Theory and Russian evidence (No. 2300). CEPR Discussion Papers.

Sonin, K. (2003). Why the rich may favor poor protection of property rights. Journal of Comparative Economics, 31(4), 715-731.

Stiglitz, J. E. (2016). Inequality and economic growth. In Rethinking Capitalism (pp. 134-155).

Sukiassyan, G. (2007). Inequality and growth: What does the transition economy data say?. Journal of Comparative Economics, 35(1), 35-56.

Svensson, J. (1998). Investment, property rights and political instability: Theory and evidence. European Economic Review, 42(7), 1317-1341.

Sylwester, K. (2000). Income inequality, education expenditures, and growth. Journal of Development Economics, 63(2), 379-398.

Tanninen, H. (1999). Income inequality, government expenditures and growth. Applied Economics, 31(9), 1109-1117. 
Thornton, J. (2001). The Kuznets inverted-U hypothesis: panel data evidence from 96 countries. Applied Economics Letters, 8(1), 15-16.

Tiwari, A. K., Shahbaz, M., \& Islam, F. (2013). Does financial development increase rural-urban income inequality? Cointegration analysis in the case of Indian economy. International Journal of Social Economics, 40(2), 151-168.

United Nations University World Institute for Development Economics Research UNU-Wider. (2018). World Income Inequality Database. Volume 4. Retrieved 2005, from https://www.wider.unu.edu/database/world-income-inequality-database-wiid4

Van der Ven, R., \& Smits, J. (2011). The demographic window of opportunity: age structure and sub-national economic growth in developing countries. Nijmegen Center for Economics (NICE) - Institute for Management Research-Radboud University Nijmegen.

Verma, R. (2007). Savings, investment and growth in India: an application of the ARDL bounds testing approach. South Asia Economic Journal, 8(1), 87-98.

Vo, D. H., Nguyen, T. C., \& Tran, N. P. (2019). What Factors Affect Income Inequality and Economic Growth in Middle-Income Countries?. Journal of Risk and Financial Management, 12(1), 40.

Voitchovsky, S. (2005). Does the profile of income inequality matter for economic growth? Journal of Economic Growth, 10(3), 273-296.

Wahiba, N. F., \& El Weriemmi, M. (2013). The relationship between economic growth and income inequality. International Journal of Economics and Financial Issues, 4(1), 135-143.

Wan, G., Lu, M., \& Chen, Z. (2006). The inequality-growth nexus in the short and long run: Empirical evidence from China. Journal of Comparative Economics, 34(4), 654-667.

World Bank. (2019). World Development Indicators 2019. New York, World Bank.

\section{Appendix I}

\section{Channels through Which Inequality Can Affect Growth Classical Approach}
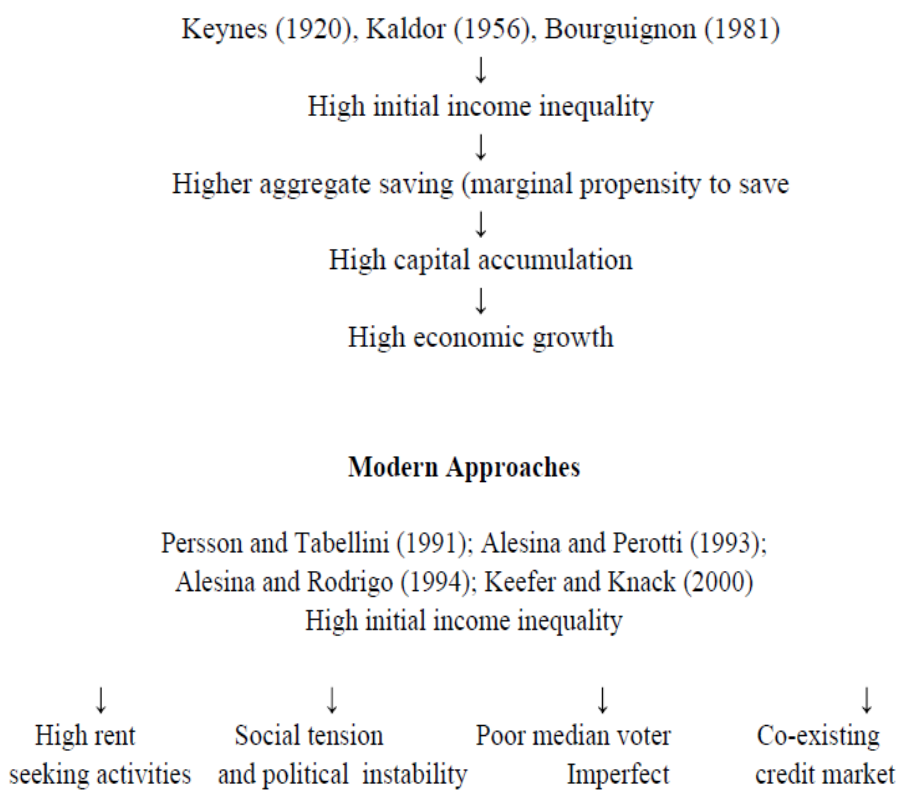

Figure 1. The classical and modern expositions views of the impact of inequality on growth Source: Adapted from Tabassum and Majeed (2008) 


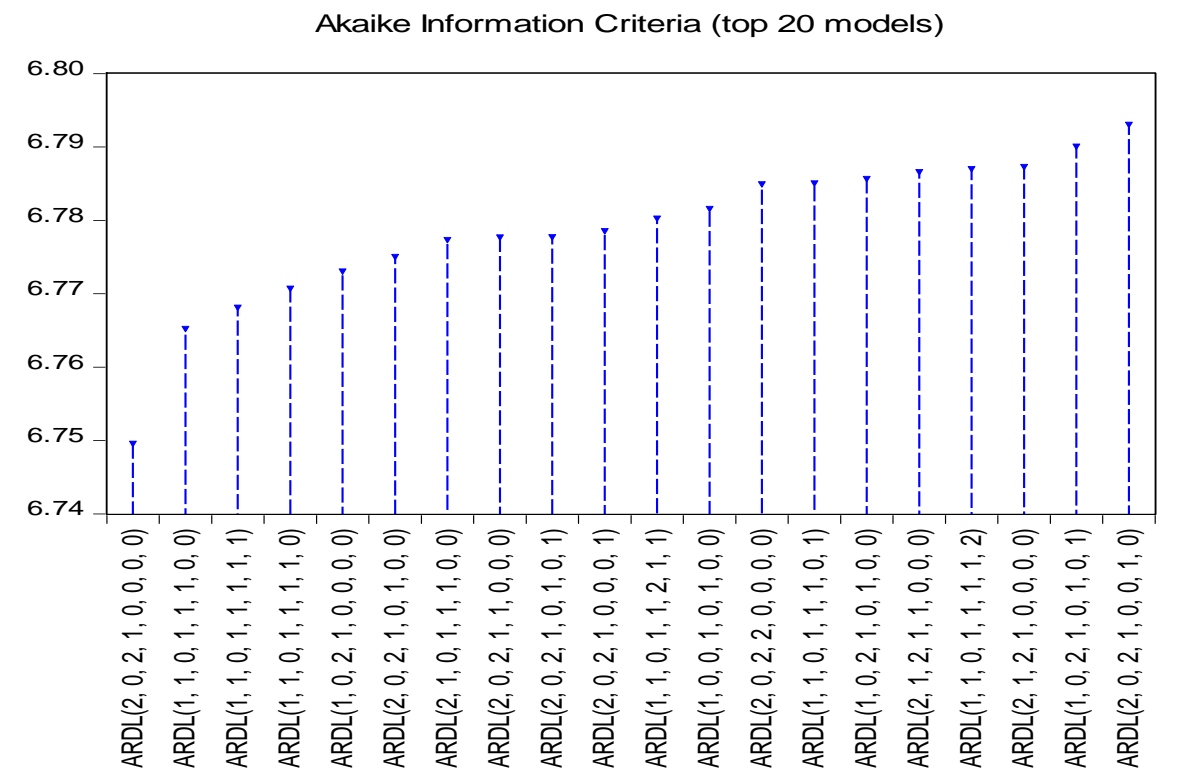

Figure 2. Model Selection Graph (Summary of the top 20 models selection) for Model 14

Akaike Information Criteria (top 20 models)

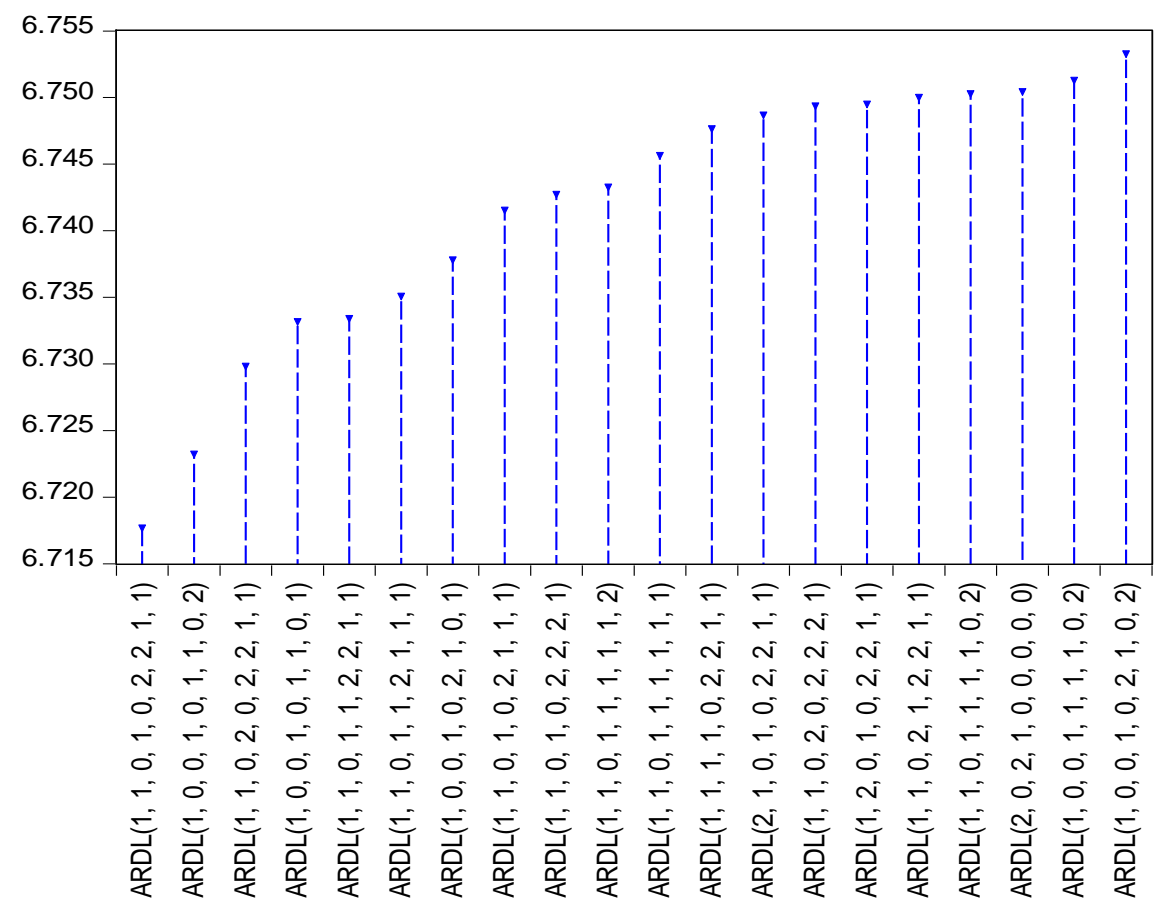

Figure 3. Model Selection Graph (Summary of the top 20 models selection) for Model 15 
Akaike Information Criteria (top 20 models)

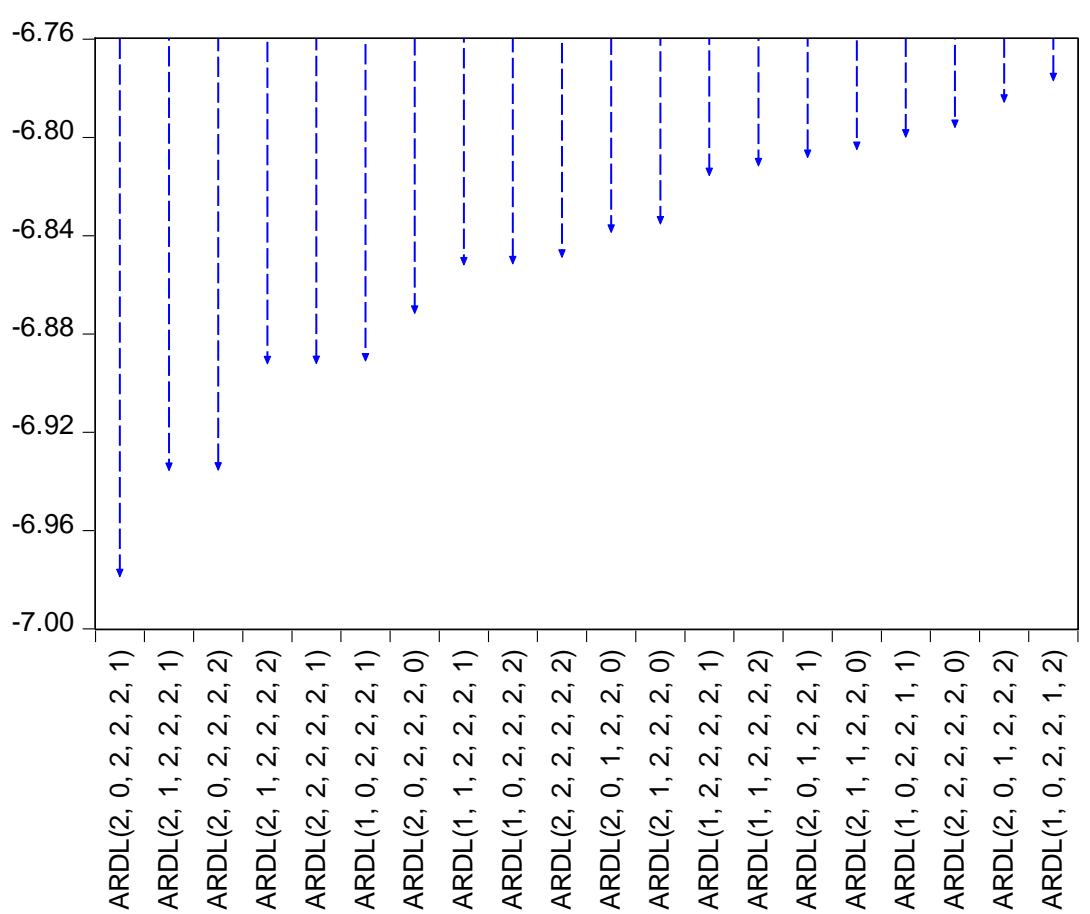

Figure 4. Model Selection Graph (Summary of the top 20 models selection) for Model 16

Akaike Information Criteria (top 20 models)

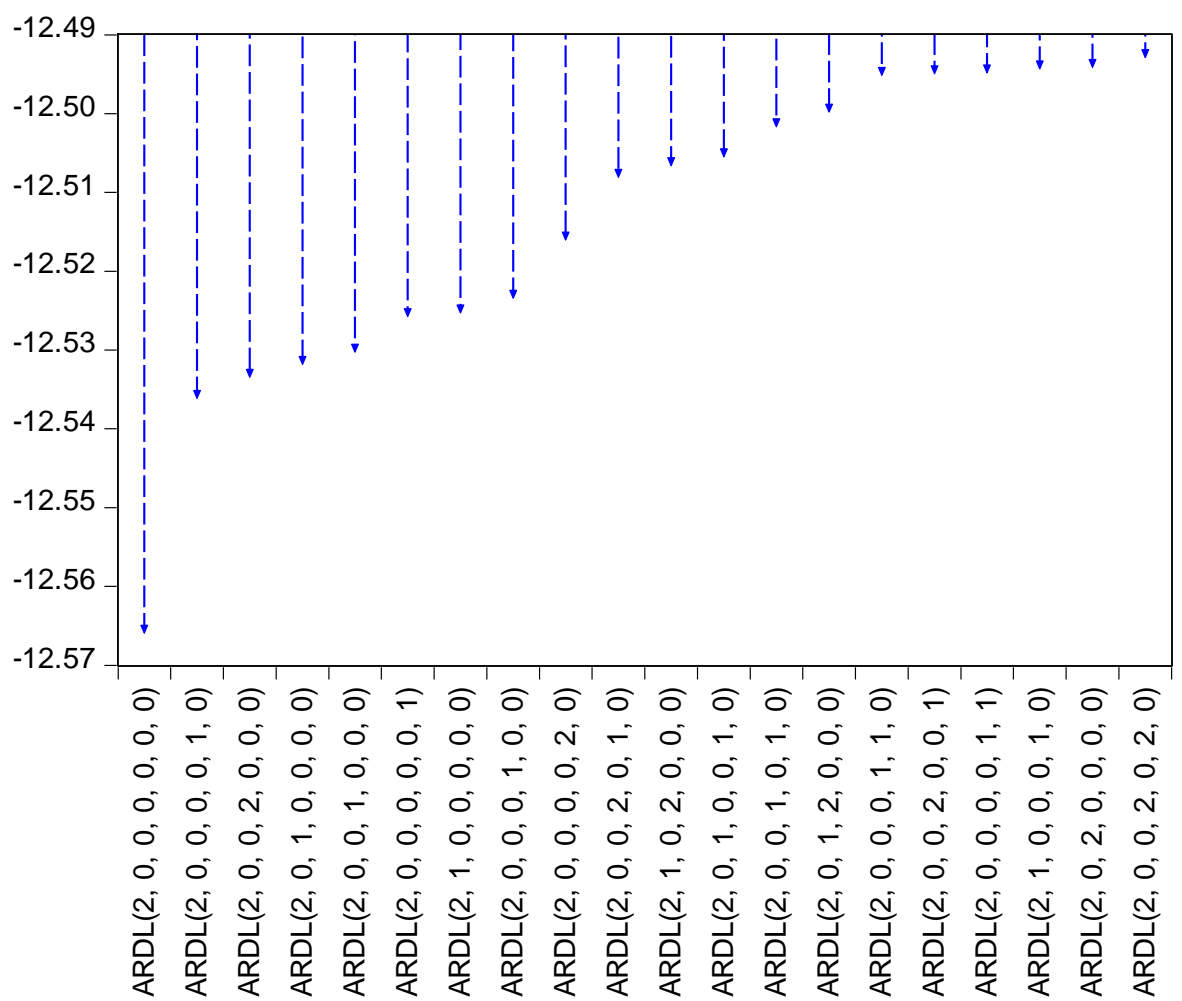

Figure 5. Model Selection Graph (Summary of the top 20 models selection) for Model 17 
Akaike Information Criteria (top 20 models)

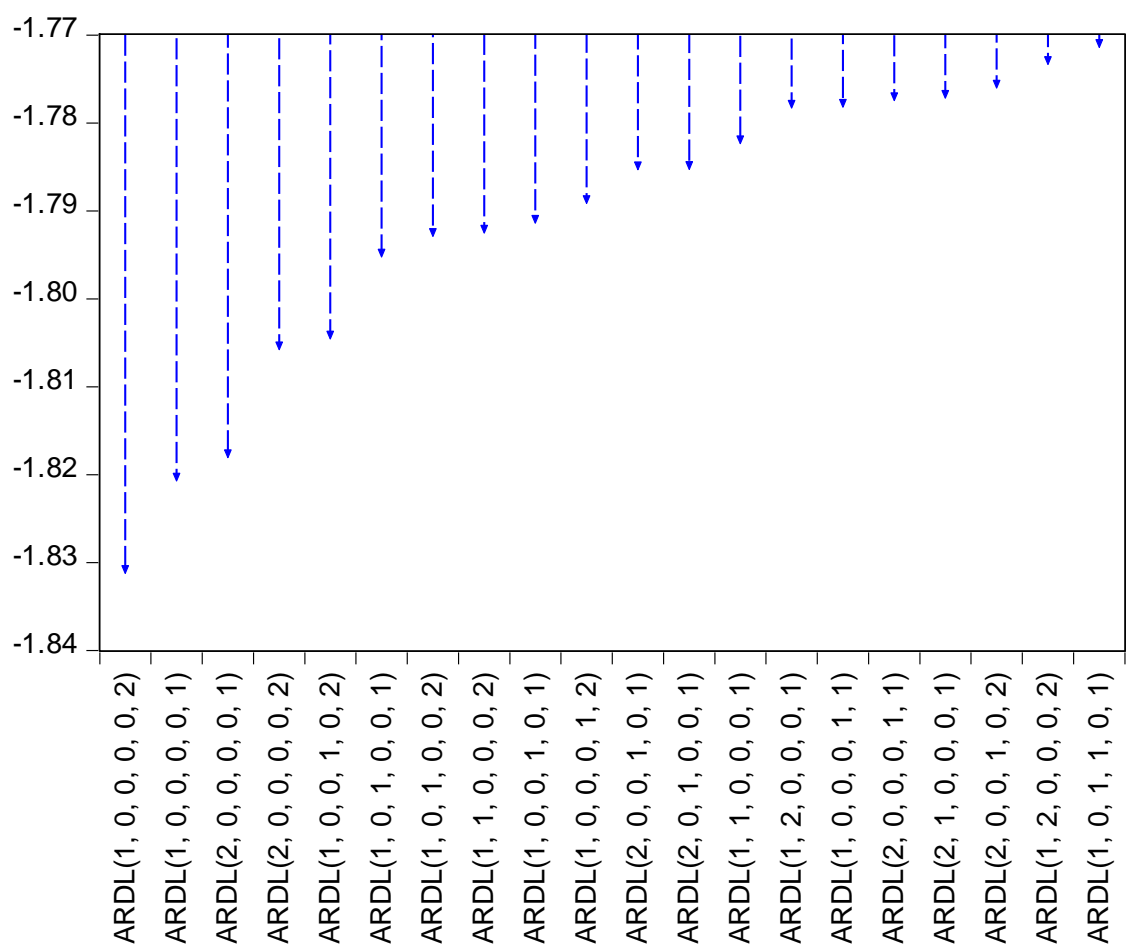

Figure 6. Model Selection Graph (Summary of the top 20 models selection) for Model 18

Akaike Information Criteria (top 20 models)

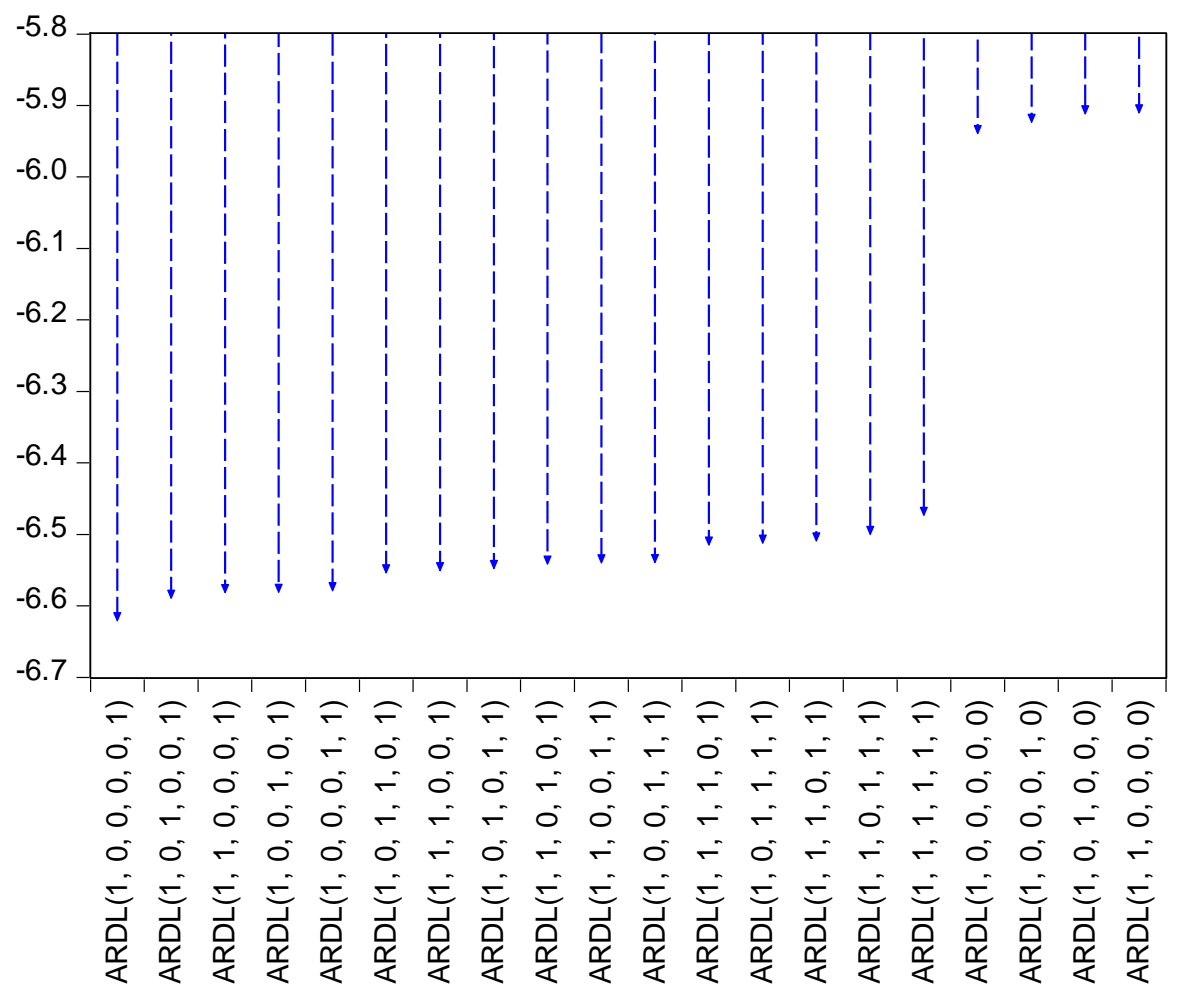

Figure 7. Model Selection Graph (Summary of the top 20 models selection) for Model 19 
Akaike Information Criteria (top 20 models)

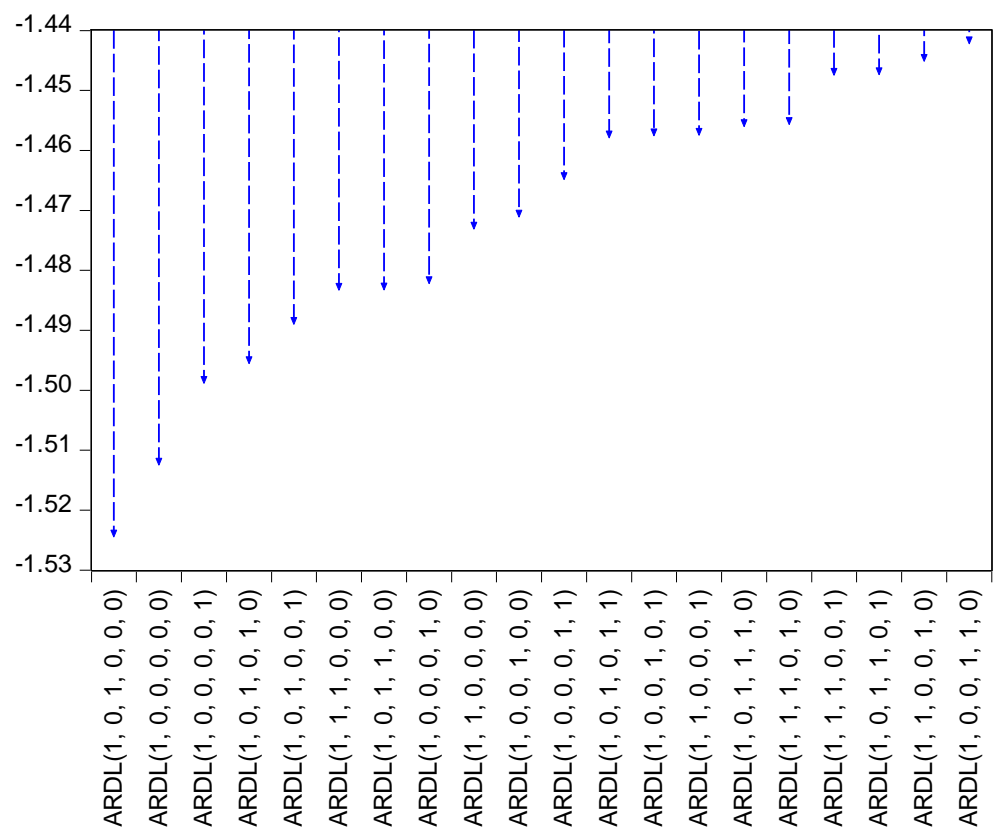

Figure 8. Model Selection Graph (Summary of the top 20 models selection) for Model 20

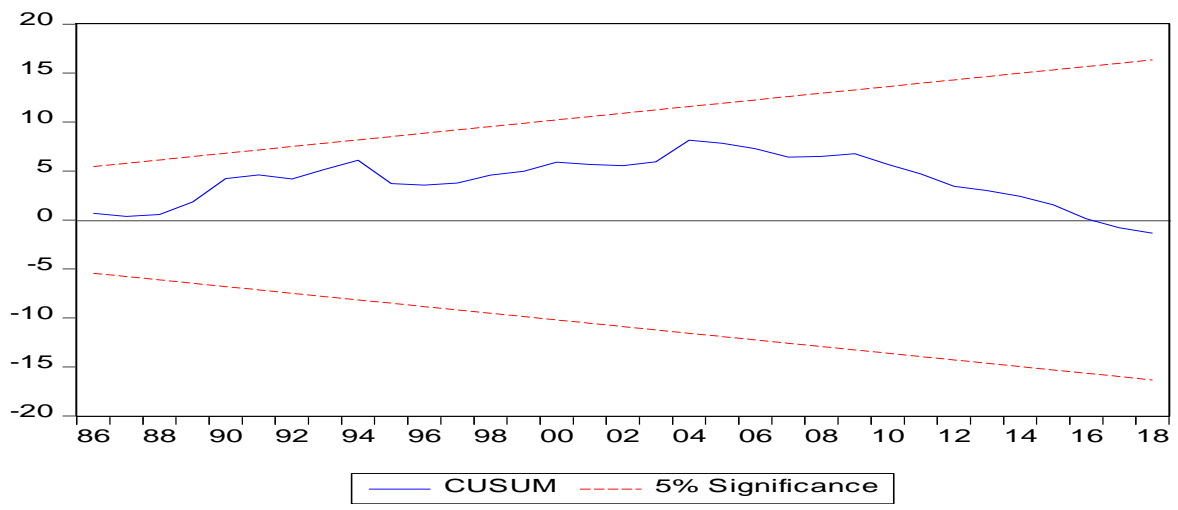

Figure 9. Plot of Cumulative Sum of Recursive Residuals CUSUM (Stability Test) for Model 14

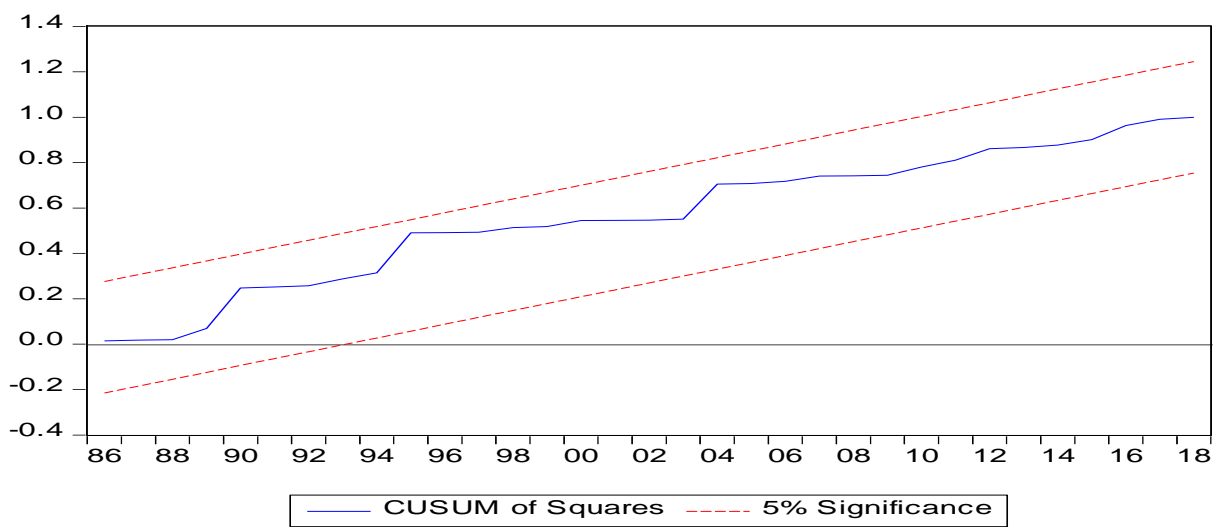

Figure 10. Plot of Cumulative Sum of Squares of Recursive Residuals CUSUMQ (Stability Test) for Model 14 


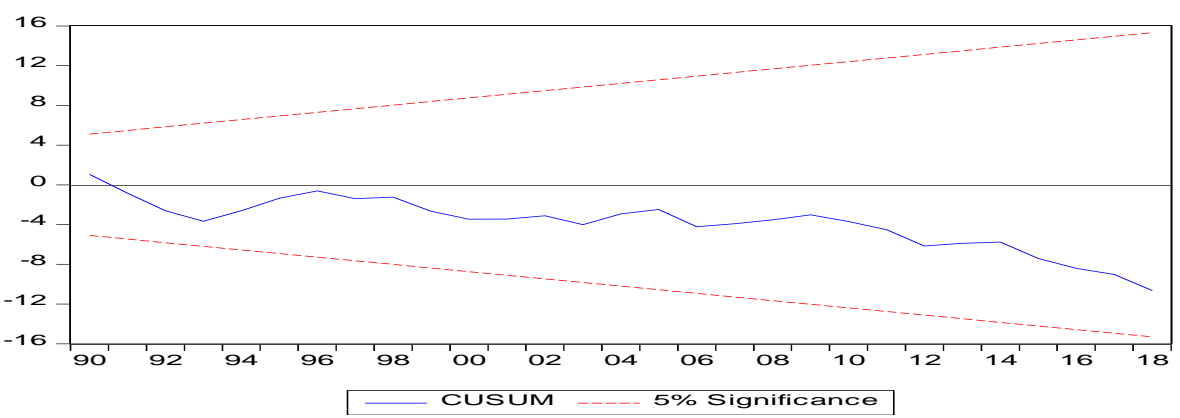

Figure 11. Plot of Cumulative Sum of Recursive Residuals CUSUM (Stability Test) for Model 15

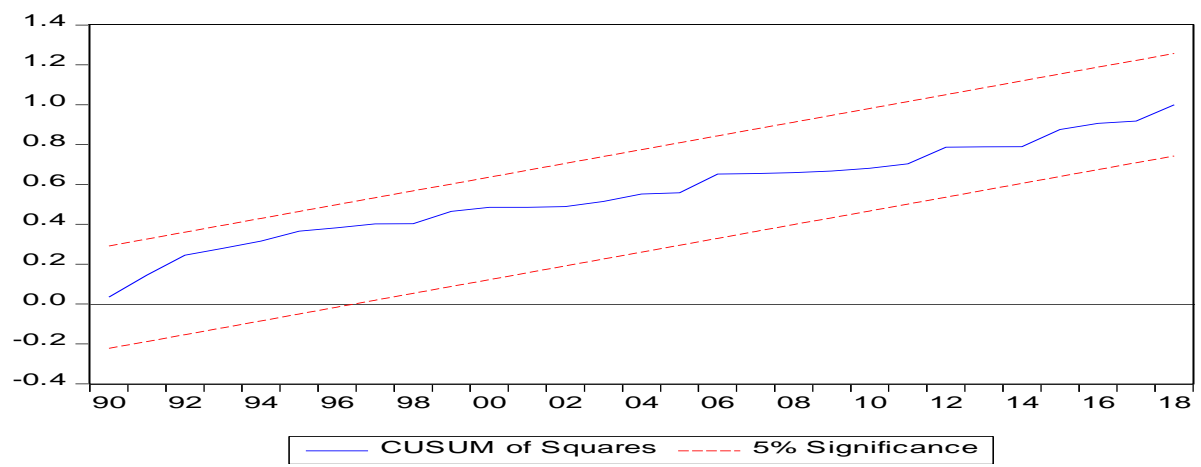

Figure 12. Plot of Cumulative Sum of Squares of Recursive Residuals CUSUMQ (Stability Test) for Model 15

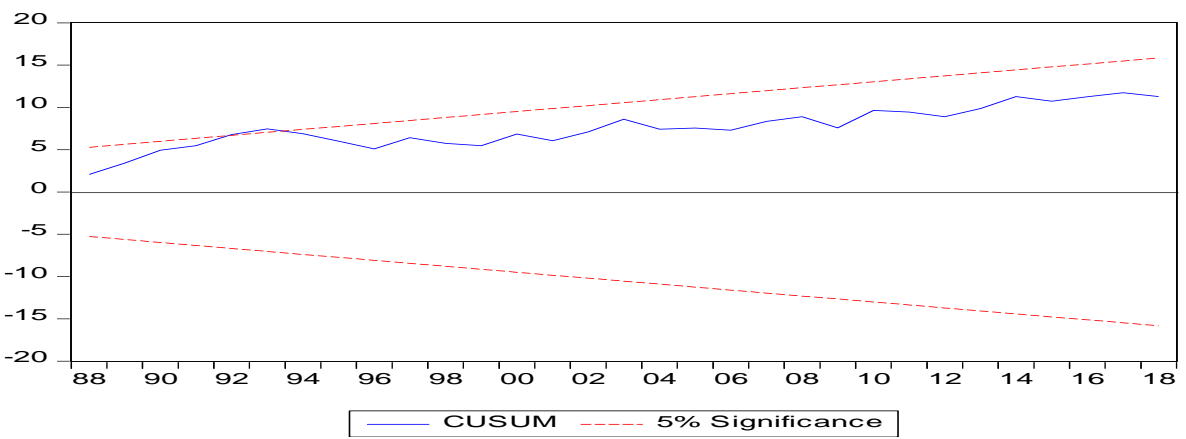

Figure 13. Plot of Cumulative Sum of Recursive Residuals CUSUM (Stability Test) for Model 16

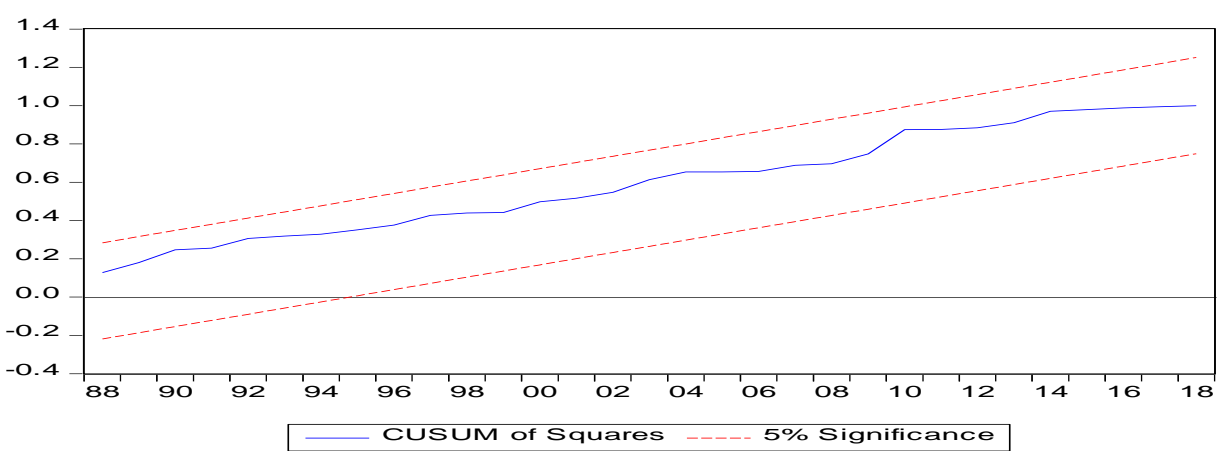

Figure 14. Plot of Cumulative Sum of Squares of Recursive Residuals CUSUMQ (Stability Test) for Model 16 


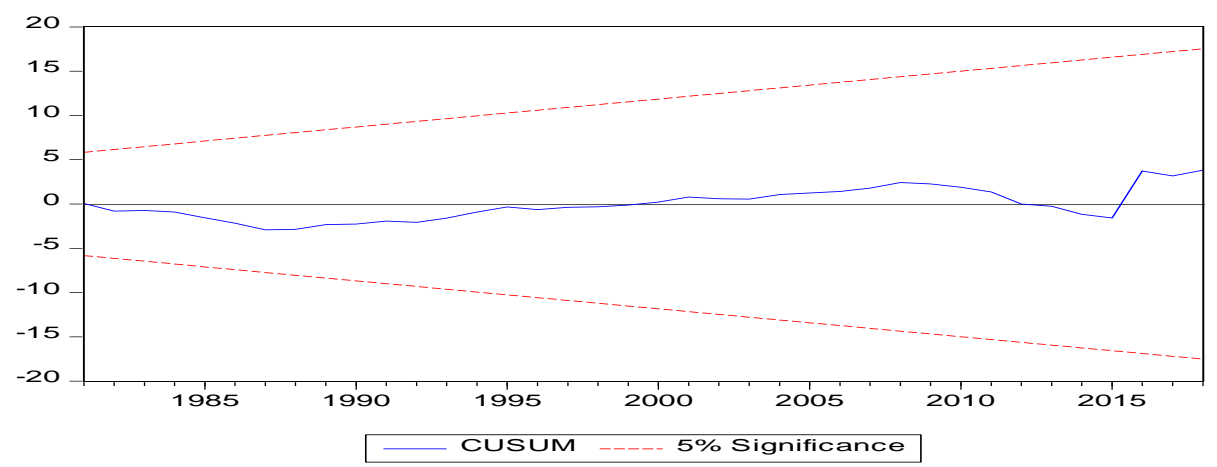

Figure 15. Plot of Cumulative Sum of Recursive Residuals CUSUM (Stability Test) for Model 17

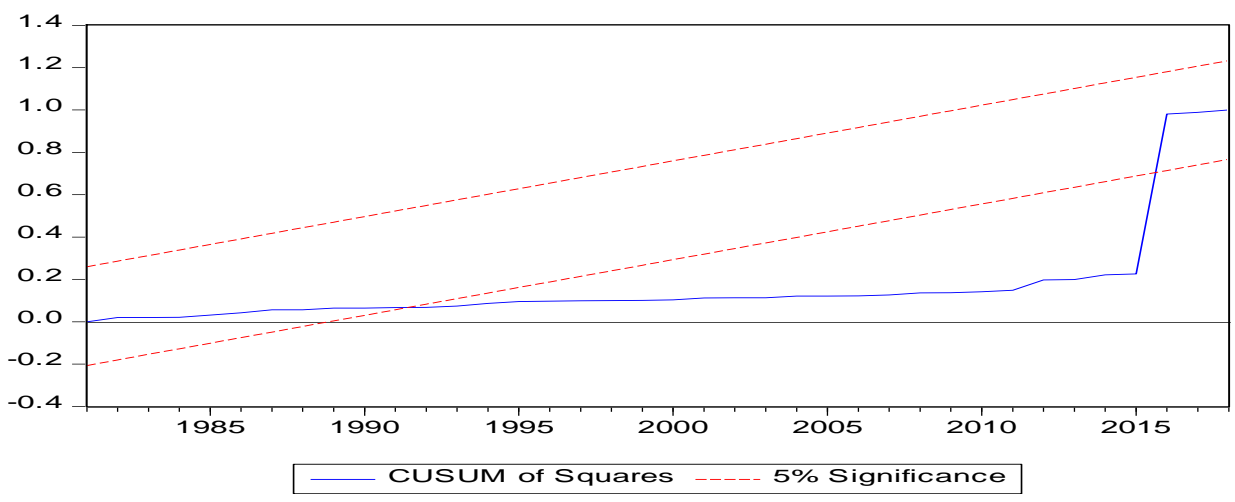

Figure 16. Plot of Cumulative Sum of Squares of Recursive Residuals CUSUMQ (Stability Test) for Model 17

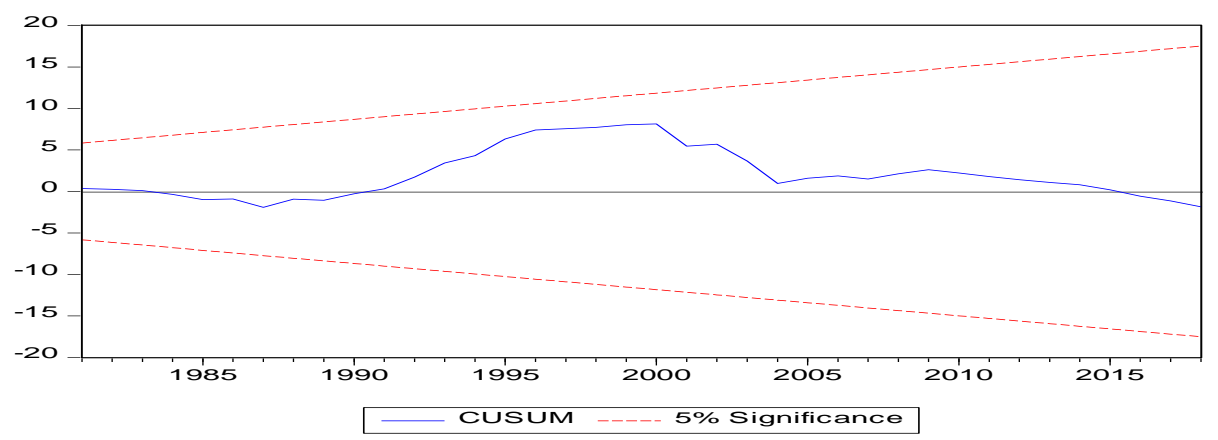

Figure 17. Plot of Cumulative Sum of Recursive Residuals CUSUM (Stability Test) for Model 18

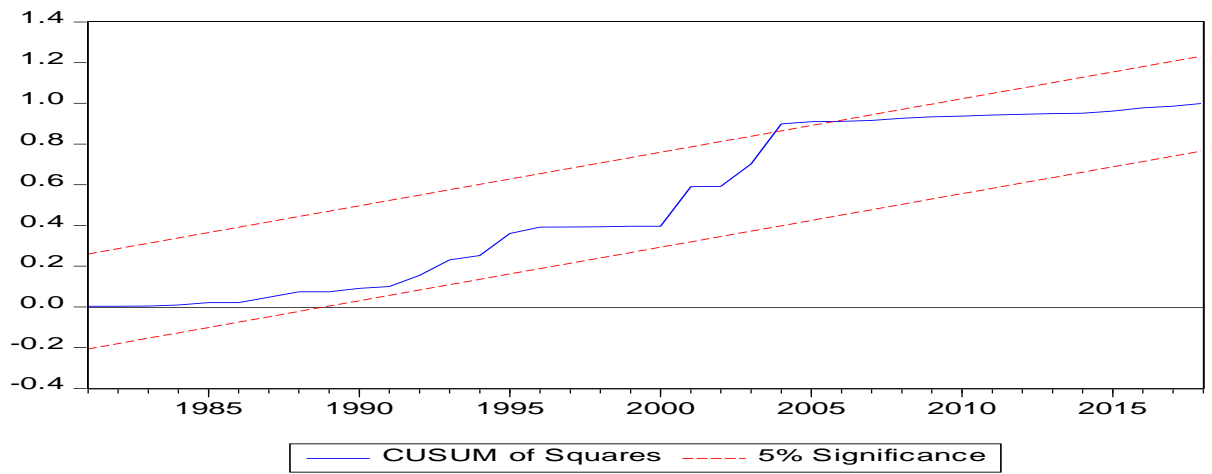

Figure 18. Plot of Cumulative Sum of Squares of Recursive Residuals CUSUMQ (Stability Test) for Model 18 


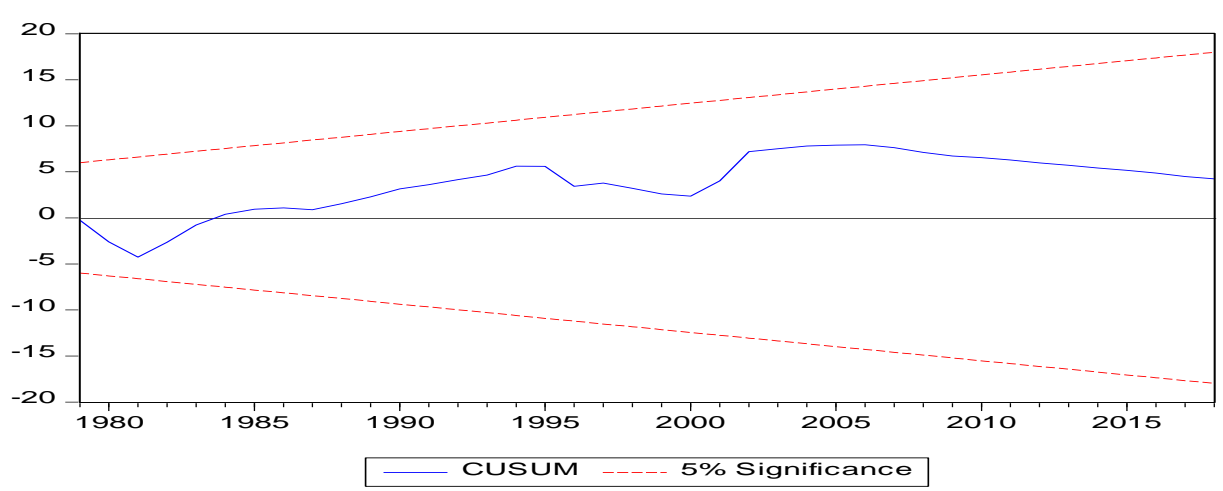

Figure 19. Plot of Cumulative Sum of Recursive Residuals CUSUM (Stability Test) for Model 19

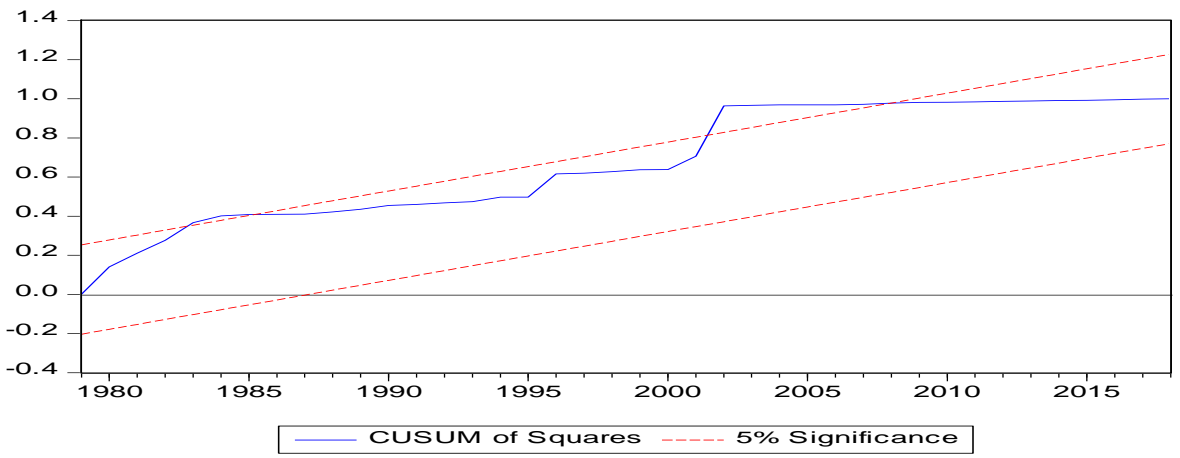

Figure 20. Plot of Cumulative Sum of Squares of Recursive Residuals CUSUMQ (Stability Test) for Model 19

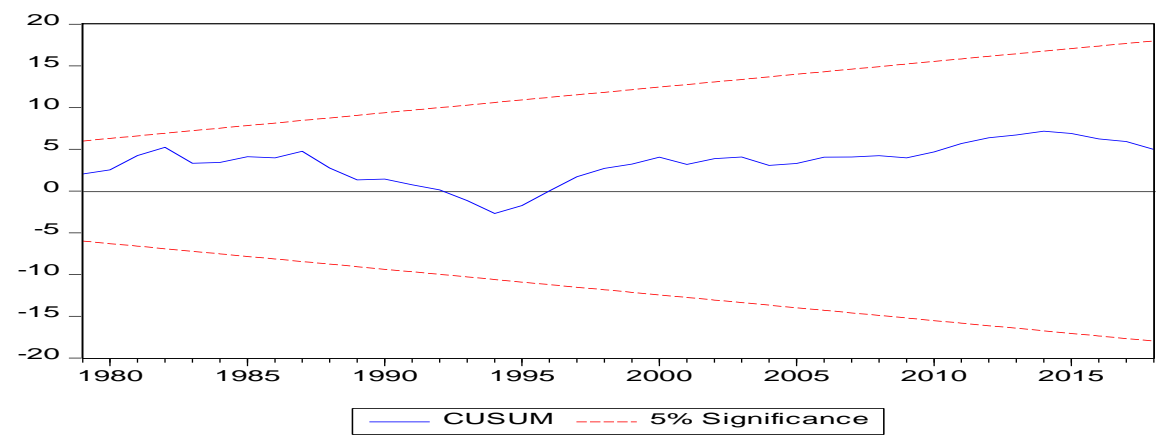

Figure 21. Plot of Cumulative Sum of Recursive Residuals CUSUM (Stability Test) for Model 20

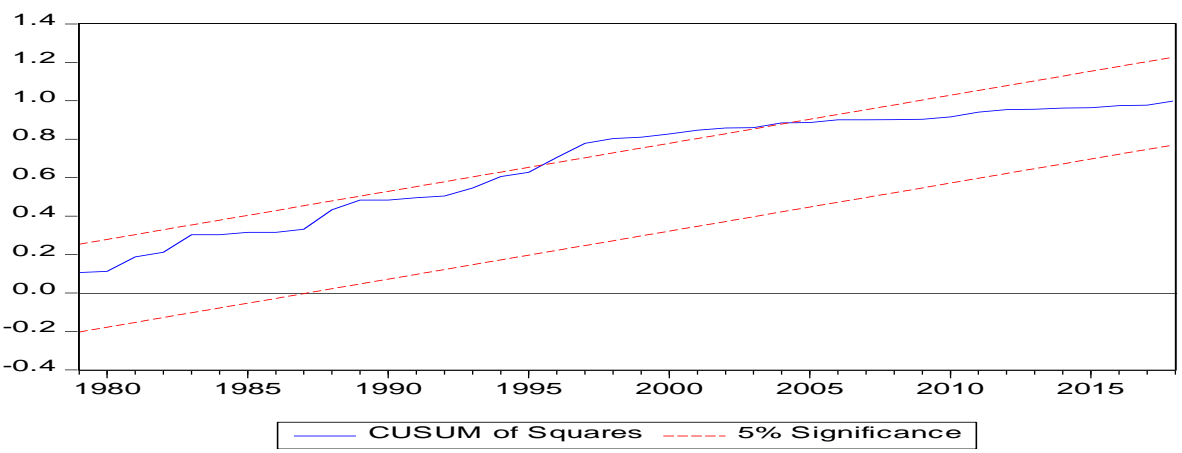

Figure 22. Plot of Cumulative Sum of Squares of Recursive Residuals CUSUMQ (Stability Test) for Model 20 


\section{Appendix II}

Table 1. An overview and synopsis of the existing literature on the impact of income inequality on economic growth

\begin{tabular}{|c|c|c|c|c|c|c|c|}
\hline Author & Samples & Data Structure & Distribution & Inequality measure & Income Inequality & Estimation & Empirical findings \\
\hline $\begin{array}{l}\text { Alesina and } \\
\text { Rodrik (1994) }\end{array}$ & $\begin{array}{l}46 / 70 \text { countries } \\
1960-1985\end{array}$ & Cross- section & Income, Land & Gini Coefficient & Jain Fields & OLS, 2SLS & $\begin{array}{l}\text { Income: Negative for the whole sample; Negative in } \\
\text { democracies and non-democracies; Insignificant when } \\
\text { income and land inequality are considered } \\
\text { simultaneously; Land: Negative for the whole sample }\end{array}$ \\
\hline $\begin{array}{l}\text { Persson and } \\
\text { Tabellini } \\
\text { (1994 }\end{array}$ & $\begin{array}{l}56 \text { countries } 1960 \\
1985\end{array}$ & Cross-section & Income & $\begin{array}{l}\text { Share of the fourth } \\
\text { quintile }\end{array}$ & Paukert & OLS, 2SLS & $\begin{array}{l}\text { Negative for the whole sample; Negative in } \\
\text { democracies and insignificant in non-democracies }\end{array}$ \\
\hline Clarke (1995) & $\begin{array}{l}74 / 81 \text { countries } \\
1970-1978\end{array}$ & Cross-section & Income & $\begin{array}{l}\text { Gini., Coef. of var., } \\
\text { Theil, th quintile } \\
\text { sh. }\end{array}$ & UN Social indicators & $\begin{array}{l}\text { OLS, WLS, } \\
\text { 2SLS }\end{array}$ & $\begin{array}{l}\text { Negative for the whole sample; Negative in } \\
\text { democracies and non-democracies }\end{array}$ \\
\hline Perotti (1996) & $\begin{array}{l}67 \text { countries } 1960 \\
1985\end{array}$ & Cross-section & Income & $\begin{array}{l}\text { Share of the } 3 \text { th and } \\
4 \text { th quintiles }\end{array}$ & Jain Lecaillon & OLS, WLS & $\begin{array}{l}\text { Negative for the whole sample; Insignificant when } \\
\text { regional dummies are added; negative in democracies } \\
\text { and nondemocracies; negative in rich and insignificant in } \\
\text { poor countries }\end{array}$ \\
\hline $\begin{array}{l}\text { Birdsall and } \\
\text { Londono } \\
\text { (1997) }\end{array}$ & $\begin{array}{l}43 \text { countries } 1960 \\
1992\end{array}$ & Cross-section & $\begin{array}{l}\text { Income, land } \\
\text { and Human } \\
\text { capital }\end{array}$ & Gini coefficient & $\begin{array}{l}\text { Deininger and } \\
\text { Squire }\end{array}$ & OLS & $\begin{array}{l}\text { Income: Negative for the whole sample; Insignificant } \\
\text { when income, land and human capital inequality are } \\
\text { considered simultaneously; Land and human capital: } \\
\text { Negative for the whole sample, even when income, land } \\
\text { and human capital inequality are considered } \\
\text { simultaneously }\end{array}$ \\
\hline $\begin{array}{l}\text { Deininger and } \\
\text { Squire (1998) }\end{array}$ & $\begin{array}{l}\text { 66/87 countries } \\
1960-1992\end{array}$ & Cross-section & Income, Land & Gini coefficient & $\begin{array}{l}\text { Deininger and } \\
\text { Squire }\end{array}$ & OLS & $\begin{array}{l}\text { Income: Negative for the whole sample; Insignificant } \\
\text { when regional dummies are added; Land: Negative for } \\
\text { the whole sample; Insignificant in democracies and } \\
\text { negative in non-democracies; Insignificant in rich and } \\
\text { negative in poor } \\
\text { countries }\end{array}$ \\
\hline $\begin{array}{l}\text { Li and Zou } \\
(1998)\end{array}$ & $\begin{array}{l}46 \text { countries } 1960 \\
1990\end{array}$ & Panel & Income & Gini coefficient & $\begin{array}{l}\text { Deininger and } \\
\text { Squire }\end{array}$ & $\mathrm{FE}, \mathrm{RE}$ & Positive for the whole sample \\
\hline
\end{tabular}

\begin{tabular}{|c|c|c|c|c|c|c|c|}
\hline Author & Samples & Data Structure & Distribution & Inequality measure & Income Inequality Data Set & Estimation method & Empirical findings \\
\hline $\begin{array}{l}\text { Deininger and } \\
\text { Olinto (1999) }\end{array}$ & $\begin{array}{l}60 \text { countries, } 1966- \\
1990\end{array}$ & Panel & Income & Gini coefficient & Deininger and Squire & System GMM & $\begin{array}{l}\text { Negative impact of land inequality and positive } \\
\text { impact of income inequality on economic growth }\end{array}$ \\
\hline $\begin{array}{l}\text { Deininger and } \\
\text { Olinto (2000) }\end{array}$ & $\begin{array}{l}31 / 60 \text { countries } \\
1966-1990\end{array}$ & Panel & Income, Land & Gini coefficient & Deininger and Squire & System GMM & $\begin{array}{l}\text { Income: Positive when income and land inequality } \\
\text { are considered simultaneously; Land: Negative for } \\
\text { the whole sample }\end{array}$ \\
\hline Forbes (2000) & $\begin{array}{l}45 \text { (mid-high inc) } \\
\text { countries 1966- } \\
1995\end{array}$ & Panel & Income & Gini coefficient & Deininger and Squire & First-diff GMM & Positive in high and mid-income countries \\
\hline Mo (2000) & $\begin{array}{l}20 \text { countries, } 1970- \\
1985\end{array}$ & Panel & Income & Gini coefficient & Deininger and Squire & 2SLS & Negative relationship \\
\hline Barro (2000) & $\begin{array}{l}84 \text { countries } 1965- \\
1995\end{array}$ & Panel & Income & Gini coefficient & Deininger and Squire & 3SLS & $\begin{array}{l}\text { Insignificant for the whole sample; Positive in rich } \\
\text { and negative in poor countries }\end{array}$ \\
\hline $\begin{array}{l}\text { Castellò and } \\
\text { Domenéch (2002) }\end{array}$ & $\begin{array}{l}67 / 83 \text { countries } \\
1960-1990\end{array}$ & Cross-section & $\begin{array}{l}\text { Income, Human } \\
\text { capital }\end{array}$ & Gini coefficient & $\begin{array}{l}\text { Deininger and Squire, Barro } \\
\text { and Lee }\end{array}$ & OLS & $\begin{array}{l}\text { Income: Negative for the whole sample; } \\
\text { Insignificant when regional dummies are added; } \\
\text { Positive when income and human capital inequality } \\
\text { are considered simultaneously; Human Capital: } \\
\text { Negative for the whole sample, even when income } \\
\text { and human capital inequality are considered } \\
\text { simultaneously }\end{array}$ \\
\hline $\begin{array}{l}\text { Balisacan and } \\
\text { Fuwa (2003) }\end{array}$ & $\begin{array}{l}\text { Philippines, } \\
\text { provincial data, } \\
1988-1997\end{array}$ & Cross-section & Land & Gini coefficient & $\begin{array}{l}\text { Census of Agriculture } \\
\text { National Statistics Office }\end{array}$ & OLS, IV & Positive relationship \\
\hline $\begin{array}{l}\text { Gylfason and } \\
\text { Zoega (2003) }\end{array}$ & $\begin{array}{l}87 \text { countries, } 1965- \\
98\end{array}$ & Cross-section & Income & Gini coefficient & Deininger and Squire & SUR & Negative relationship \\
\hline $\begin{array}{l}\text { De La Croix and } \\
\text { Doepke (2003) }\end{array}$ & $\begin{array}{l}68 \text { countries, } 1960- \\
1992\end{array}$ & Panel & Income & Gini coefficient & Deininger and Squire & Difference GMM & $\begin{array}{l}\text { Negative relationship, which becomes } \\
\text { nonsignificant if fertility rate is taken into account }\end{array}$ \\
\hline Chen (2003) & $\begin{array}{l}54 \text { countries } 1970- \\
1992\end{array}$ & Panel & Income & Gini coefficient & $\begin{array}{l}\text { Deininger and Squire, Barro } \\
\text { and Lee }\end{array}$ & OLS & Inverted-U relationship \\
\hline
\end{tabular}




\begin{tabular}{|c|c|c|c|c|c|c|c|}
\hline Author & Samples & Data Structure & Distribution & Inequality measure & Income Inequality Data Set & Estimation method & Empirical findings \\
\hline $\begin{array}{l}\text { Banerjee and } \\
\text { Duflo (2003) }\end{array}$ & $\begin{array}{l}45 \text { countries } 1965- \\
1995\end{array}$ & Panel & Income & Gini coefficient & Deininger and Squire & $\begin{array}{l}\text { Fixed,Random,Panel } \\
\text {; First Difference; } \\
\text { Arellano and Bond }\end{array}$ & $\begin{array}{l}\text { Negative effect on growth resulting } \\
\text { from changes in inequality in any } \\
\text { direction }\end{array}$ \\
\hline Pagano (2004) & $\begin{array}{l}40 \text { countries, } 1950- \\
1990\end{array}$ & Panel & Income & Gini coefficient & $\begin{array}{l}\text { Dollar and Kraay, UNU- } \\
\text { WIDER }\end{array}$ & $\begin{array}{l}\text { Difference and } \\
\text { system GMM }\end{array}$ & $\begin{array}{l}\text { Positive relationship in rich } \\
\text { countries, negative relationship in } \\
\text { poor ones }\end{array}$ \\
\hline Iradian (2005) & $\begin{array}{l}82 \text { countries, } \\
1965-2003\end{array}$ & Panel & Income & Gini coefficient & PRSPs, WDI, IMF, OECD & $\begin{array}{l}\text { FE and difference } \\
\text { GMM }\end{array}$ & $\begin{array}{l}\text { Positive relationship in the short- } \\
\text { medium term, which becomes } \\
\text { negative in the long term }\end{array}$ \\
\hline $\begin{array}{l}\text { Knowles } \\
(2005)\end{array}$ & $\begin{array}{l}40 \text { countries } 1960- \\
1990\end{array}$ & Cross-section & Income & Gini coefficient & Deininger and Squire & OLS & $\begin{array}{l}\text { Negative for the whole sample; } \\
\text { Insignificant for high/midincome } \\
\text { countries and negative for low- } \\
\text { income countries; Insignificant for } \\
\text { gross-income and negative for } \\
\text { expenditures }\end{array}$ \\
\hline $\begin{array}{l}\text { Voitchovsky } \\
\text { (2005) }\end{array}$ & $\begin{array}{l}21 \text { (developed) } \\
\text { countries 1975- } \\
2000\end{array}$ & Panel & Income & $\begin{array}{l}\text { Gini coefficient; 90/75 } \\
\text { and 50/10 ratios }\end{array}$ & Luxembourg Income Study & System GMM & $\begin{array}{l}\text { Insignificant considering aggregate } \\
\text { inequality; Positive at the top of } \\
\text { inequality distribution; Negative at } \\
\text { the bottom of inequality distribution }\end{array}$ \\
\hline $\begin{array}{l}\text { Wan, Lu and } \\
\text { Chen (2006) }\end{array}$ & $\begin{array}{l}\text { China, } 29 \text { regions, } \\
1987-1998\end{array}$ & Cross-section & Income & $\begin{array}{l}\text { Urban-rural per capita } \\
\text { income ratio }\end{array}$ & $\begin{array}{l}\text { UNUWIDER World } \\
\text { Income Inequality } \\
\text { Database. }\end{array}$ & $\begin{array}{l}\text { Polynomial Inverse } \\
\text { Lag Model, 3SLS }\end{array}$ & Negative nonlinear relationship \\
\hline Easterly (2007) & $\begin{array}{l}100 \text { countries, } 1960 \\
1998\end{array}$ & Panel & Income & $\begin{array}{l}\text { Gini coefficient, share of } \\
\text { top income quintile }\end{array}$ & $\begin{array}{l}\text { UNUWIDER World } \\
\text { Income Inequality } \\
\text { Database. }\end{array}$ & OLS, IV & Negative relationship \\
\hline $\begin{array}{l}\text { Sukiassyan } \\
(2007)\end{array}$ & $\begin{array}{l}26 \text { transition } \\
\text { economies, 1988- } \\
2002\end{array}$ & Panel & Income & Gini coefficient & $\begin{array}{l}\text { TransMONEE } 2004 \\
\text { Database, World Bank } \\
\text { Poverty Monitoring } \\
\text { Indicators 2004 Database } \\
\text { (PMI), and WIID } \\
\end{array}$ & $\begin{array}{l}\text { OLS and difference } \\
\text { GMM with Gini } \\
\text { squared among the } \\
\text { covariates }\end{array}$ & Negative relationship \\
\hline
\end{tabular}

\begin{tabular}{|c|c|c|c|c|c|c|c|}
\hline Author & Samples & Data $S$ & Distribution & Inequality measure & Income Inequality Data Set & Estimation method & Empirical findings \\
\hline $\begin{array}{l}\text { Noh and Yoo } \\
(2008)\end{array}$ & $\begin{array}{l}60 \text { countries, } 1995- \\
2002\end{array}$ & Panel & Income & Gini coefficient & UNU-WIDER & $\mathrm{FE}$ & Positive relationship \\
\hline Barro (2008) & $\begin{array}{l}47-70 \text { countries, } \\
1965-2003 / 4\end{array}$ & Panel & Income & Gini coefficient & WIID & OLS & $\begin{array}{l}\text { Positive relationship in rich } \\
\text { countries, negative relationship in } \\
\text { the poor ones. }\end{array}$ \\
\hline $\begin{array}{l}\text { Lin and Yeh } \\
\text { (2009) }\end{array}$ & $\begin{array}{l}83 \text { countries, } 1965- \\
2003\end{array}$ & Panel & Income & Gini coefficient & PRSPs, WDI, IMF, OECD & $\begin{array}{l}\text { SEM, difference } \\
\text { GMM }\end{array}$ & Negative relationship \\
\hline $\begin{array}{l}\text { Chambers and } \\
\text { Krause (2010) }\end{array}$ & $\begin{array}{l}54 \text { countries, 1960- } \\
2000\end{array}$ & Panel & Income & Gini coefficient & $\begin{array}{l}\text { UNUWIDER World } \\
\text { Income Inequality } \\
\text { Database. }\end{array}$ & $\begin{array}{l}\text { Local Linear Least } \\
\text { Squares, Gaussian } \\
\text { kernel }\end{array}$ & Negative relationship \\
\hline Castellò (2010) & $\begin{array}{l}102 / 56 \text { countries } \\
1960-2000\end{array}$ & Panel & $\begin{array}{l}\text { Income, } \\
\text { Human capital }\end{array}$ & $\begin{array}{l}\text { Gini coefficient, } \\
\text { Distribution of education } \\
\text { by quintiles }\end{array}$ & $\begin{array}{l}\text { UNUWIDER Luxembourg } \\
\text { Income Study }\end{array}$ & System GMM & $\begin{array}{l}\text { Income: Negative for the whole } \\
\text { sample; Negative for poor and } \\
\text { positive for rich countries; Human } \\
\text { Capital: Negative for the whole } \\
\text { sample; Negative for poor and } \\
\text { inconclusive for rich countries }\end{array}$ \\
\hline Grijalva (2011) & $\begin{array}{l}100 \text { countries, } 1950 \\
2007\end{array}$ & -Panel & Income & Gini coefficient & $\begin{array}{l}\text { UNUWIDER World } \\
\text { Income Inequality } \\
\text { Database. }\end{array}$ & $\begin{array}{l}\text { FE, RE, difference } \\
\text { and system GMM }\end{array}$ & $\begin{array}{l}\text { Inverted "U" relationship the short } \\
\text { and medium term ( } 5-10 \text { years). In } \\
\text { the long term the results confirm } \\
\text { Barro ( } 2008\end{array}$ \\
\hline $\begin{array}{l}\text { Herzer and } \\
\text { Vollmer (2012) }\end{array}$ & $\begin{array}{l}46 \text { countries, } 1970- \\
1995\end{array}$ & Panel & Income & Gini coefficient & Deininger and Squire & Panel cointegration & Negative relationship \\
\hline $\begin{array}{l}\text { Ravallion } \\
\text { (2012) }\end{array}$ & $\begin{array}{l}90 \text { countries, 1980- } \\
2005\end{array}$ & Panel & Income & Gini coefficient & Deininger and Squire & Difference GMM & $\begin{array}{l}\text { Inequality does not have a } \\
\text { statistically significant impact on } \\
\text { growth once we control for initial } \\
\text { poverty }\end{array}$ \\
\hline Assa (2012) & $\begin{array}{l}141 \text { countries, } 1998 \\
2008\end{array}$ & -Panel & Income & Gini coefficient & WDI & OLS, 2SLS & $\begin{array}{l}\text { Negative relationship in the } \\
\text { developing countries, less evident in } \\
\text { the advanced economies }\end{array}$ \\
\hline
\end{tabular}




\begin{tabular}{|c|c|c|c|c|c|c|c|}
\hline Author & Samples & Data Structure & Distribution & Inequality measure & Income Inequality Data Set & Estimation method & Empirical findings \\
\hline $\begin{array}{l}\text { Ostry, Berg } \\
\text { and } \\
\text { Tsangarides } \\
\text { (2014) }\end{array}$ & $\begin{array}{l}90 \text { countries } 1960- \\
2010\end{array}$ & Panel & $\begin{array}{l}\text { (Market and } \\
\text { disposable) } \\
\text { Income }\end{array}$ & Gini coefficient & SWIID & System GMM & $\begin{array}{l}\text { Look at both net inequality and } \\
\text { redistribution (the difference } \\
\text { between market and disposable } \\
\text { income inequality). Inequality is } \\
\text { estimated to have a negative effect } \\
\text { on growth, redistribution is not } \\
\text { significant. }\end{array}$ \\
\hline $\begin{array}{l}\text { Halter, } \\
\text { Oechslin and } \\
\text { Zweimuller } \\
\text { (2014) }\end{array}$ & $\begin{array}{l}90 \text { countries 1966- } \\
2005\end{array}$ & Panel & Income & Gini coefficient & $\begin{array}{l}\text { Deininger and Squire, } \\
\text { UNUWIDER }\end{array}$ & $\begin{array}{l}\text { System GMM, First- } \\
\text { diff GMM }\end{array}$ & $\begin{array}{l}\text { First-diff GMM: positive link in } \\
\text { whole and in sub-samples by } \\
\text { income. System GMM: positive in } \\
\text { rich and negative in poor countries }\end{array}$ \\
\hline $\begin{array}{l}\text { Bagchi and } \\
\text { Svejnar (2015) }\end{array}$ & $\begin{array}{l}41 \text { countries, } 2015 \\
1987-2002\end{array}$ & Panel & $\begin{array}{l}\text { Income, } \\
\text { Wealth }\end{array}$ & Gini coefficient & $\begin{array}{l}\text { A wealth inequality index } \\
\text { derived by Forbes } \\
\text { magazine's list of } \\
\text { billionaires, UNUWIDER }\end{array}$ & RE, FE, IV & Negative relationship \\
\hline $\begin{array}{l}\text { Chletsos and } \\
\text { Fatouros, N. } \\
\text { (2016) }\end{array}$ & $\begin{array}{l}126 \text { countries } \\
(1968-2007)\end{array}$ & Panel & Income & Theil Index & $\begin{array}{l}\text { Estimated Household } \\
\text { Income Inequality Data Set } \\
\text { (EHII) }\end{array}$ & FE, GMM, 2SLS & Positive relationship \\
\hline Islam (2017) & $\begin{array}{l}\text { Single Country } \\
(1960-2015)\end{array}$ & Time Series & Income & $\begin{array}{l}\text { The market Gini } \\
\text { coefficients and the top } 1 \\
\text { percent income shares }\end{array}$ & $\begin{array}{l}\text { The Standardized World } \\
\text { Income Inequality } \\
\text { Database, SWIID,of Solt } \\
\text { (2016) }\end{array}$ & $\begin{array}{l}\text { ARDL, DOLS, } \\
\text { FMOLS and } \\
\text { Canonical } \\
\text { Cointegrating } \\
\text { Regression CCR) } \\
\end{array}$ & Negative relationship \\
\hline Naguib (2017) & $\begin{array}{l}146 \text { countries, } 2010- \\
2014\end{array}$ & Panel & $\begin{array}{l}\text { Income, } \\
\text { Wealth }\end{array}$ & Gini coefficient & $\begin{array}{l}\text { SWIID, Credit Suisse } \\
\text { Research Institute }\end{array}$ & $\begin{array}{l}\text { Arellano- Bond } \\
\text { GMM }\end{array}$ & $\begin{array}{l}\text { Positive relationship though not } \\
\text { robust to different model } \\
\text { specifications }\end{array}$ \\
\hline Joshi (2018) & 24, Indian States & Cross-country & Income & Gini coefficient & $\mathrm{Pal}$ and $\mathrm{Pal}(2012)$ & OLS & Posittive relationship \\
\hline
\end{tabular}

Source: Adapted and Updated from Cingano (2014)

Table 2. Data Sources, Description and Justification of Variables

\begin{tabular}{|c|c|c|c|}
\hline Variable & Proxy & Sources & Justifications \\
\hline $\begin{array}{l}\text { Economic } \\
\text { Growth }\end{array}$ & $\begin{array}{l}\text { RGDP per capita growth } \\
\text { (annual \%) }\end{array}$ & $\begin{array}{l}\text { World Development Indicators } \\
\text { (2019) }\end{array}$ & $\begin{array}{l}\text { Devarajan, Swaroop and Zou (1996), Loayza and } \\
\text { Ranciere (2004), El-Wassal (2012), Andreano, Laureti, } \\
\text { and Postiglione (2013), Naguib (2017). }\end{array}$ \\
\hline $\begin{array}{l}\text { Income (Output) } \\
\text { per worker }\end{array}$ & $\begin{array}{l}\text { GDP per person employed } \\
\text { (constant } 2011 \mathrm{PPP} \$)\end{array}$ & $\begin{array}{l}\text { World Development Indicators } \\
(2019)\end{array}$ & $\begin{array}{l}\text { Mody and Aiyar (2011);Van der Ven, and Smits (2011); } \\
\text { Chletsos and Fatouros (2016); Kazbekova (2018) }\end{array}$ \\
\hline Labour Force & Growth rate of the labour force (\%) & Penn World Table 9.0 & $\begin{array}{l}\text { Denton and Spencer (1997), Raleva (2014), Njindan } \\
\text { Iyke and Ho (2017), Mbarek, Saidi, and Rahman (2018) }\end{array}$ \\
\hline Population & Growth rate of the population (\%) & $\begin{array}{l}\text { World Development Indicators } \\
\text { (2019) }\end{array}$ & $\begin{array}{l}\text { Ram (1984); Cincotta and Engelman (1997); Klasen and } \\
\text { Lawson (2007); Rehman, Khan and Ahmed (2008); } \\
\text { Odusola, Mugisha, Workie, and Reeves (2017) }\end{array}$ \\
\hline $\begin{array}{l}\text { Financial } \\
\text { Deepening }\end{array}$ & The ratio of broad money to GDP & $\begin{array}{l}\text { Central Bank of Nigeria Statistical } \\
\text { Bulletin (2019) }\end{array}$ & $\begin{array}{l}\text { Patrick (1966),Shaw (1973), McKinnon (1973, 2010), } \\
\text { Luintel and Khan (1999), Kirkpatrick, Sirageldin, and } \\
\text { Aftab (2000), Ghildiyal, Pokhriyal, and Mohan (2015). }\end{array}$ \\
\hline $\begin{array}{l}\text { Human Capital } \\
\text { Accumulation }\end{array}$ & Gross Enrollment Ratio & $\begin{array}{l}\text { World Development Indicators } \\
\text { (2019) }\end{array}$ & $\begin{array}{l}\text { Romer (1989, 1990), Mankiw, Romer, and Weil (1992), } \\
\text { Islam (1995), Adawo (2011), Sieng and Yussof (2014), } \\
\text { Amir, Khan, and Bilal (2015) }\end{array}$ \\
\hline Trade Openness & $\begin{array}{l}\text { The ratio of sum of exports and } \\
\text { imports to GDP }\end{array}$ & $\begin{array}{l}\text { Central Bank of Nigeria Statistical } \\
\text { Bulletin (2019) }\end{array}$ & $\begin{array}{l}\text { Majeed (2010); Lim and McNelis (2014); Lai, Tan, Ong, } \\
\text { and Lee (2015); Oloufade (2012); Lahouij (2017). }\end{array}$ \\
\hline $\begin{array}{l}\text { Income } \\
\text { Inequality }\end{array}$ & Gini Coefficient & $\begin{array}{l}\text { United Nations University World } \\
\text { Income Inequality Database WIID } \\
3.4\end{array}$ & $\begin{array}{l}\text { Alesina and Rodrik (1994), Deininger and Squire (1998), } \\
\text { Forbes (2000), Barro (2000, 2008), Ostry et al, (2014). }\end{array}$ \\
\hline $\begin{array}{l}\text { Poverty } \\
\text { Incidence }\end{array}$ & $\begin{array}{l}\text { The headcount ratio (per capita } \\
\text { final consumption expenditure) }\end{array}$ & $\begin{array}{l}\text { Central Bank of Nigeria Statistical } \\
\text { Bulletin (2019) }\end{array}$ & $\begin{array}{l}\text { Ravallion (1997, 2017); Quartney (2005); Odhiambo } \\
\text { (2009); Ho, and Odhiambo, (2011); Kar, Agir, and } \\
\text { Peker (2011); Nindi and Odhiambo (2015). }\end{array}$ \\
\hline Investment Rate & $\begin{array}{l}\text { The ratio of fixed investment to } \\
\text { GDP }\end{array}$ & $\begin{array}{l}\text { United Nations Statistics Division } \\
\text { National Accounts Main } \\
\text { Aggregates Database (2019) }\end{array}$ & $\begin{array}{l}\text { Barro (2000); Banerjee (2004); Ehrhart (2009); Er, } \\
\text { Tugcu, and Coban (2014); Dabús and Caraballo (2014); } \\
\text { Lahouij (2017) }\end{array}$ \\
\hline $\begin{array}{l}\text { Total Fertilty } \\
\text { Rate }\end{array}$ & $\begin{array}{l}\text { Fertility Rate (The average number } \\
\text { of children that would be born to a } \\
\text { woman over her lifetime) }\end{array}$ & $\begin{array}{l}\text { World Development Indicators } \\
\text { (2019) }\end{array}$ & $\begin{array}{l}\text { Galor and Zang (1997); De La Croix and Doepke } \\
\text { (2003); Li and Zhang (2007); Schultz (2008); Macan and } \\
\text { Deluna (2013); Charles-Coll, Granados, and De la Garza } \\
\text { Ramos (2015). }\end{array}$ \\
\hline Mortality Rate & $\begin{array}{l}\text { Infant Mortality Rate (The number } \\
\text { of deaths of children under one } \\
\text { year of age per } 1000 \text { live births) }\end{array}$ & $\begin{array}{l}\text { World Development Indicators } \\
\text { (2019) }\end{array}$ & $\begin{array}{l}\text { Deaton (2003); Deaton and Paxson (2004); Rebeira, } \\
\text { Grootendorst, Coyte and Aguirregabiria (2017); Lahouij } \\
\text { (2017); Ray and Linden (2018). }\end{array}$ \\
\hline $\begin{array}{l}\text { Relative } \\
\text { Redistribution }\end{array}$ & $\begin{array}{l}\text { The ratio of the difference between } \\
\text { market Gini and net Gini to the } \\
\text { market Gini }\end{array}$ & $\begin{array}{l}\text { Standardized World Income } \\
\text { Inequality Database (SWIID, } \\
\text { 2019) }\end{array}$ & $\begin{array}{l}\text { Shin (2012); Dahlby and Ferede (2013); Delbianco, } \\
\text { Dabús and Caraballo (2014); Luebker (2014); Gründler } \\
\text { and Scheuermeyer (2015); Islam (2017). }\end{array}$ \\
\hline $\begin{array}{l}\text { Property rights } \\
\text { protection }\end{array}$ & $\begin{array}{l}\text { Fraser Institute's Legal structure } \\
\text { and security of property rights } \\
\text { index (Economic Freedom of the } \\
\text { World Index, EFW) }\end{array}$ & $\begin{array}{l}\text { Fraser Institute, Vancouver - } \\
\text { James Gwartney, Robert Lawson, } \\
\text { Michael Walker, Walter Block, } \\
\text { Stephen T. Easton }\end{array}$ & $\begin{array}{l}\text { Sonin (1999, 2003); Gradstein (2007); Besley and } \\
\text { Ghatak (2010); Locke (2013); Amendola, Easaw, and } \\
\text { Savoia (2013); Islam (2017). }\end{array}$ \\
\hline
\end{tabular}

Source: Author's computation (2019) 
Table 3. Descriptive Statistics of Data Series

\begin{tabular}{|l|c|c|c|c|c|c|c|c|c|c|c|c|c|c|}
\hline & $\partial \ln \hat{\boldsymbol{q}}$ & $\ln \boldsymbol{q}$ & $\partial \ln L$ & $\partial \ln N$ & $\ln \boldsymbol{\operatorname { l n }} \boldsymbol{H}$ & $\ln \boldsymbol{T}$ & $\ln \boldsymbol{G}$ & $\ln \boldsymbol{P}$ & $\partial \ln F R$ & $\partial \ln M R$ & $\ln P R$ & $\partial \ln I N$ & $\ln R D$ \\
\hline Mean & 1.263601 & 9.71338 & 0.02119 & -0.0272 & 3.0589 & 16.7755 & -4.2236 & 3.81246 & 9.40962 & 6.26962 & 4.70458 & 1.514 & -0.1055 & -0.0860 \\
\hline Median & 1.524086 & 9.63391 & 0.02568 & -0.0270 & 3.04552 & 16.8452 & -5.1326 & 3.79549 & 9.32606 & 6.303 & 4.82028 & 1.60744 & -0.0688 & -0.0631 \\
\hline Maximum & 30.35658 & 13.3249 & 0.07044 & -0.0244 & 3.76737 & 17.4117 & -1.2472 & 4.1239 & 13.2427 & 6.783 & 5.13226 & 2.03732 & 0.34858 & 0.17633 \\
\hline Minimum & -15.4548 & 5.72031 & -0.0383 & -0.0319 & 2.30678 & 15.1732 & -7.7206 & 3.56953 & 5.33644 & 5.4271 & 4.13724 & 0.78846 & -0.9728 & -0.4610 \\
\hline Std. Dev. & 7.729431 & 2.54169 & 0.01948 & 0.00155 & 0.32143 & 0.6324 & 1.9381 & 0.14414 & 2.60773 & 0.41141 & 0.25927 & 0.38393 & 0.30806 & 0.16487 \\
\hline Skewness & 1.046798 & 0.00212 & -0.5790 & -1.3897 & -0.3629 & -1.08654 & 0.20096 & 0.42712 & 0.01711 & -0.3642 & -0.6681 & -0.4975 & -1.0682 & -0.4735 \\
\hline Kurtosis & 6.605925 & 1.51652 & 4.4348 & 4.9611 & 3.11589 & 3.28984 & 1.65225 & 2.3385 & 1.51241 & 1.9132 & 2.5114 & 2.0307 & 3.89491 & 2.4267 \\
\hline Jarque-Bera & 35.49609 & 4.49316 & 6.79964 & 22.6602 & 1.1029 & 9.81274 & 4.03835 & 2.38323 & 4.52047 & 3.49491 & 4.13241 & 3.93978 & 10.5068 & 2.50191 \\
\hline Probability & 0.700000 & 0.10576 & 0.30338 & 0.12000 & 0.57611 & 0.0074 & 0.13277 & 0.30373 & 0.10433 & 0.17422 & 0.12667 & 0.13947 & 0.00523 & 0.28623 \\
\hline Sum & 61.91647 & 475.956 & 1.01730 & -1.2773 & 149.886 & 821.999 & -206.95 & 186.811 & 461.071 & 307.211 & 230.524 & 74.1858 & -4.9586 & -4.2163 \\
\hline Sum Sq. Dev. & 2867.717 & 310.088 & 0.01784 & 0.00011 & 4.95912 & 19.1965 & 180.299 & 0.99724 & 326.412 & 8.12426 & 3.22665 & 7.07531 & 4.36551 & 1.30468 \\
\hline Observations & 49 & 49 & 49 & 49 & 49 & 49 & 49 & 49 & 49 & 49 & 49 & 49 & 49 & 49 \\
\hline
\end{tabular}

Source: Author's computation using E-view 10 (2019)

Table 4. Stationarity Tests of Variables: Augmented Dickey-Fuller (ADF) Test

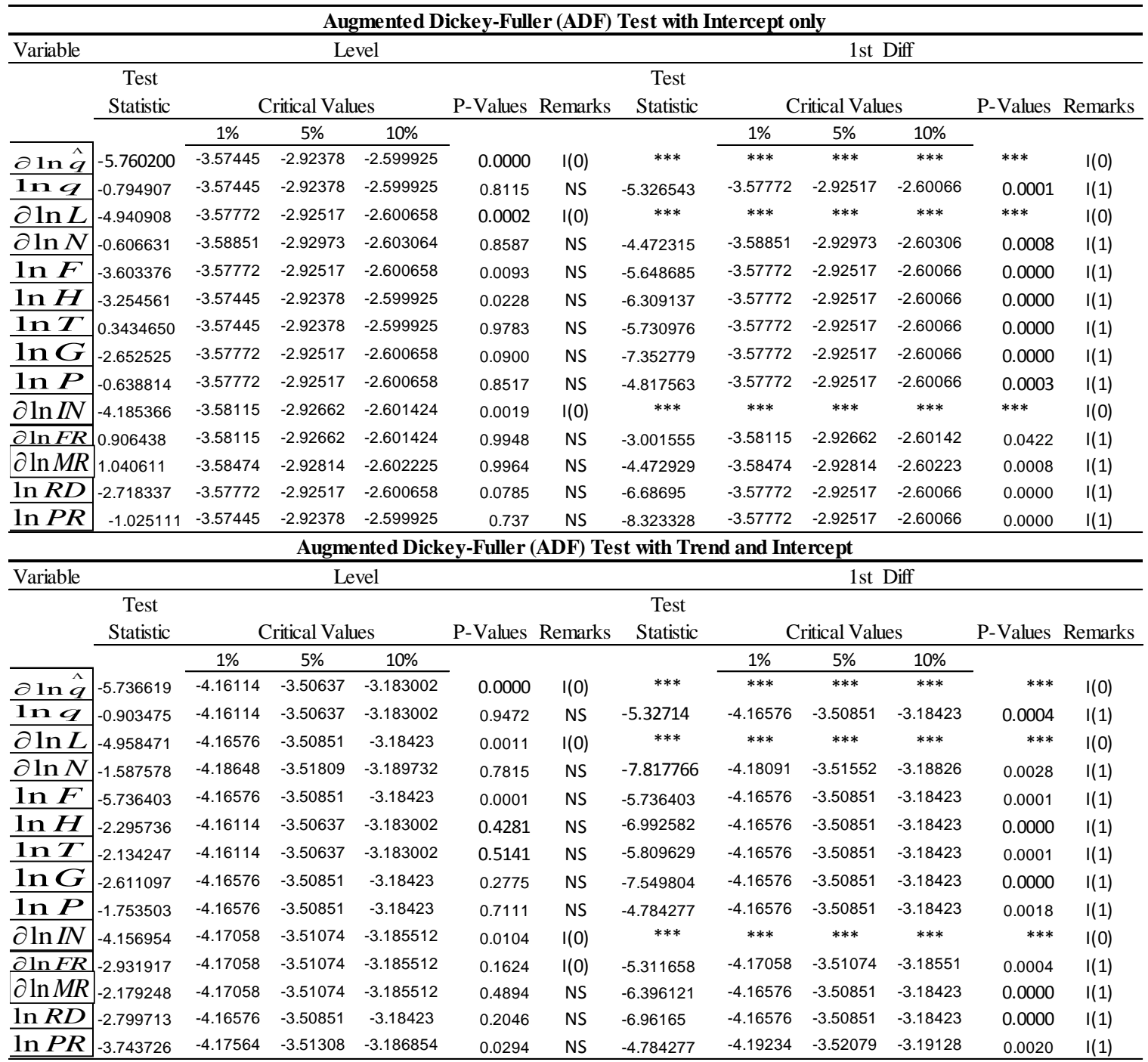

Source: Author's computation using E-view 10 (2019) 
Table 5. Stationarity Tests of Variables: Philips-Peron (PP) Test

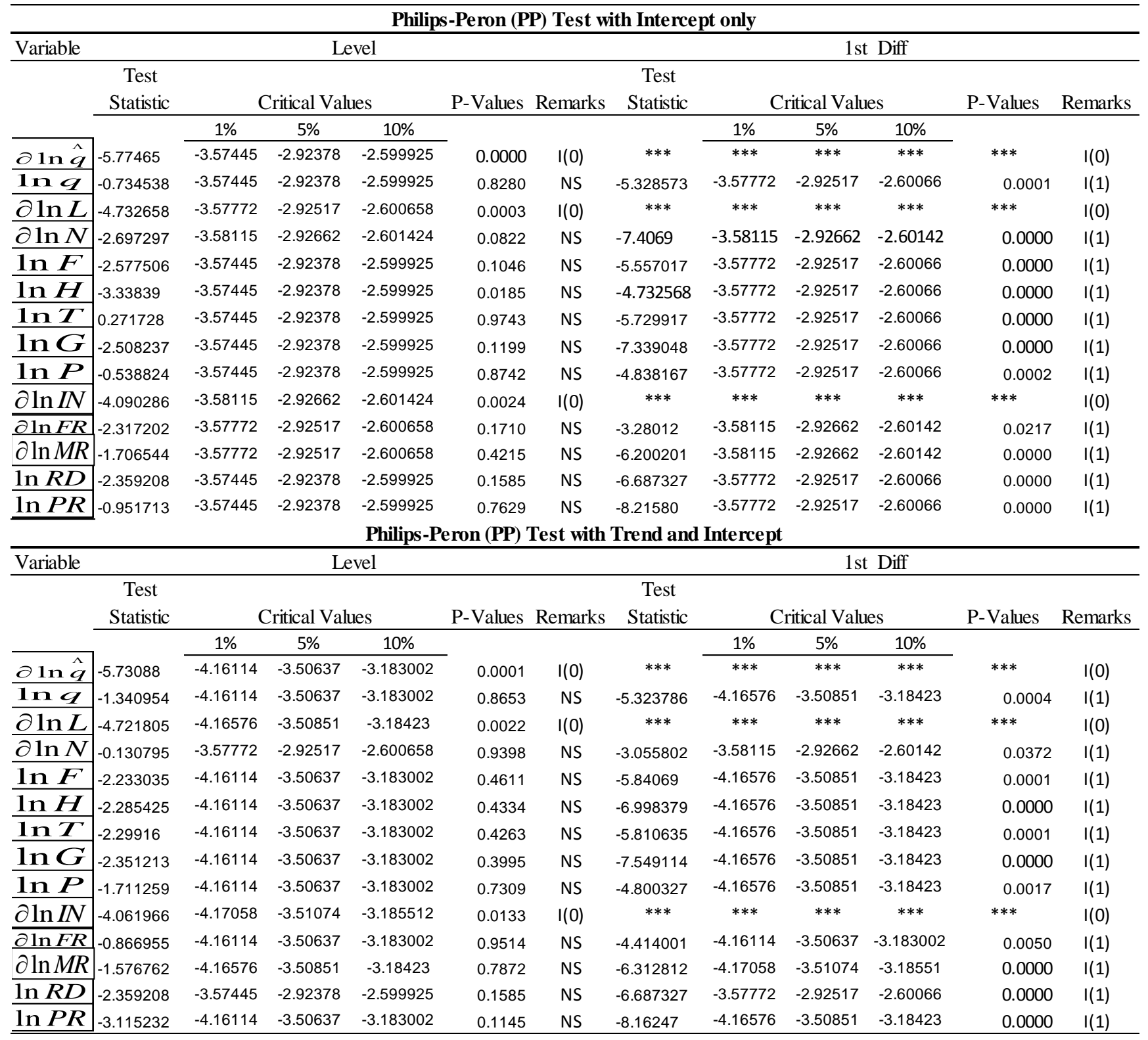

Source: Author's computation using E-view 10 (2019) 
Table 6. Optimal Lag Length Selection Criteria Results

\begin{tabular}{|c|c|c|c|c|c|}
\hline \multicolumn{6}{|c|}{ Lag Length Selection Criteria Results for Model 14} \\
\hline Lag & LR & FPE & $\mathrm{AIC}$ & $\mathrm{SC}$ & HQ \\
\hline 0 & NA & $1.15 \mathrm{E}-16$ & -13.99455 & -13.67652 & -13.87541 \\
\hline 1 & 513.2222 & $1.84 \mathrm{E}-21$ & -25.08281 & $-22.22059 *$ & -24.0106 \\
\hline 2 & $134.9300 *$ & $3.65 e-22 *$ & $-26.95296 *$ & -21.54654 & $-24.92768^{*}$ \\
\hline \multicolumn{6}{|c|}{ Lag Length Selection Criteria Results for Model 15} \\
\hline Lag & LR & FPE & AIC & $\mathrm{SC}$ & HQ \\
\hline 0 & NA & $1.35 \mathrm{E}-18$ & -15.60451 & -15.24673 & -15.47049 \\
\hline 1 & 527.0924 & $2.13 E-23$ & -26.72423 & $-23.14645^{*}$ & -25.38397 \\
\hline 2 & 142.3651* & $5.57 e-24 *$ & $-28.47527^{*}$ & -21.6775 & $-25.92878^{*}$ \\
\hline \multicolumn{6}{|c|}{ Lag Length Selection Criteria Results for Model 16} \\
\hline Lag & LR & FPE & $\mathrm{AIC}$ & $\mathrm{SC}$ & $\mathrm{HQ}$ \\
\hline 0 & NA & 3.90E-07 & 2.269201 & 2.507719 & 2.358551 \\
\hline 1 & 313.3143 & $6.13 \mathrm{E}-10$ & -4.199283 & $-2.529654^{*}$ & $-3.573830 *$ \\
\hline 2 & $62.64788 *$ & $4.76 \mathrm{e}-10^{*}$ & $-4.532486 *$ & -1.431746 & -3.37093 \\
\hline \multicolumn{6}{|c|}{ Lag Length Selection Criteria Results for Model 17} \\
\hline Lag & LR & FPE & $\mathrm{AIC}$ & $\mathrm{SC}$ & HQ \\
\hline 0 & NA & $5.01 \mathrm{E}-09$ & 0.752287 & 1.027841 & 0.85598 \\
\hline 1 & 753.1796 & $1.69 \mathrm{E}-16$ & -16.4749 & -14.27047 & -15.64536 \\
\hline 2 & 216.3903* & $1.81 \mathrm{e}-18^{*}$ & $-21.15199 *$ & $-17.01868 *$ & $-19.59660 *$ \\
\hline \multicolumn{6}{|c|}{ Lag Length Selection Criteria Results for Model 18} \\
\hline Lag & LR & FPE & $\mathrm{AIC}$ & $\mathrm{SC}$ & $\mathrm{HQ}$ \\
\hline 0 & NA & $2.85 \mathrm{E}-06$ & 4.26052 & 4.496709 & 4.3494 \\
\hline 1 & 510.1995 & $3.87 \mathrm{E}-11$ & -6.962552 & -5.309229 & -6.340395 \\
\hline 2 & $142.2021 *$ & $2.94 \mathrm{e}-12^{*}$ & $-9.613052 *$ & $-6.542594 *$ & $-8.457618^{*}$ \\
\hline \multicolumn{6}{|c|}{ Lag Length Selection Criteria Results for Model 19} \\
\hline Lag & LR & FPE & $\mathrm{AIC}$ & $\mathrm{SC}$ & HQ \\
\hline 0 & NA & $6.95 \mathrm{E}-07$ & 2.847798 & 3.083987 & 2.936678 \\
\hline 1 & $357.8877^{*}$ & $4.24 \mathrm{e}-10^{*}$ & $-4.567480 *$ & $-2.914157^{*}$ & $-3.945323^{*}$ \\
\hline 2 & 46.90032 & $5.32 \mathrm{E}-10$ & -4.414986 & -1.344528 & -3.259552 \\
\hline \multicolumn{6}{|c|}{ Lag Length Selection Criteria Results for Model 20} \\
\hline Lag & LR & FPE & $\mathrm{AIC}$ & $\mathrm{SC}$ & HQ \\
\hline 0 & NA & $6.81 \mathrm{E}-05$ & 7.432939 & 7.669128 & 7.521819 \\
\hline 1 & $330.6577^{*}$ & $8.21 \mathrm{e}-08^{*}$ & $0.698413^{*}$ & $2.351736^{*}$ & $1.320569 *$ \\
\hline 2 & 39.25301 & $1.29 \mathrm{E}-07$ & 1.075827 & 4.146285 & 2.231261 \\
\hline
\end{tabular}

Source: Author's computation using E-view 10 (2019)

* indicates lag order selected by the criterion

LR: sequential modified LR test statistic (each test at 5\% level)

FPE: Final prediction error

AIC: Akaike information criterion

SC: Schwarz information criterion

HQ: Hannan-Quinn information criterion 
Table 7. Results of Bound Test Approach to Cointegration

Results of Bound Test Approach to Cointegration for Model 14

\begin{tabular}{|c|c|c|c|}
\hline Significance & \multicolumn{2}{|c|}{ Critical Value Bonds } & Computed F-Statistic \\
\hline & $\begin{array}{c}\text { Lower Bound } \\
\text { ((O) }\end{array}$ & $\begin{array}{c}\text { Upper Bond } \\
\text { I(1) }\end{array}$ & \\
\hline $10 \%$ & 1.92 & 2.89 & 3.661152 \\
\hline $5 \%$ & 2.17 & 3.21 & \\
\hline $2.5 \%$ & 2.43 & 3.51 & \\
\hline $1 \%$ & 2.73 & 3.9 & \\
\hline \multicolumn{4}{|c|}{ Results of Bound Test Approach to Cointegration for Model 15} \\
\hline Significance & \multicolumn{2}{|c|}{ Critical Value Bonds } & Computed F-Statistic \\
\hline & $\begin{array}{c}\text { Lower Bound } \\
\mathrm{I}(\mathrm{O})\end{array}$ & $\begin{array}{l}\text { Upper Bond } \\
\text { I(1) }\end{array}$ & \\
\hline $10 \%$ & 1.85 & 2.85 & 3.738379 \\
\hline $5 \%$ & 2.11 & 3.15 & \\
\hline $2.5 \%$ & 2.33 & 3.42 & \\
\hline $1 \%$ & 2.62 & 3.77 & \\
\hline
\end{tabular}

Results of Bound Test Approach to Cointegration for Model 16

Significance Critical Value Bonds Computed F-Statistic

Lower Bound Upper Bond

\begin{tabular}{cccc} 
& $I(O)$ & $I(1)$ & \\
\cline { 2 - 3 } $10 \%$ & 2.08 & 3 & 10.44276 \\
$5 \%$ & 2.39 & 3.38 & \\
$2.5 \%$ & 2.7 & 3.73 & \\
$1 \%$ & 3.06 & 4.15 &
\end{tabular}

Results of Bound Test Approach to Cointegration for Model 17

\begin{tabular}{cccc}
\hline Significance & \multicolumn{2}{c}{ Critical Value Bonds } & Computed F-Statistic \\
\hline & $\begin{array}{c}\text { Lower Bound } \\
\mathrm{I}(0)\end{array}$ & $\begin{array}{c}\text { Upper Bond } \\
\mathrm{I}(1)\end{array}$ & \\
\cline { 2 - 3 } $10 \%$ & 1.99 & 2.94 & \multirow{13.80097}{13.909}{} \\
$5 \%$ & 2.27 & 3.28 & \\
$2.5 \%$ & 2.55 & 3.61 & \\
$1 \%$ & 2.88 & 3.99 &
\end{tabular}

Results of Bound Test Approach to Cointegration for Model 18

\begin{tabular}{cccc}
\hline Significance & \multicolumn{2}{c}{ Critical Value Bonds } & Computed F-Statistic \\
\hline & $\begin{array}{c}\text { Lower Bound } \\
\mathrm{I}(0)\end{array}$ & $\begin{array}{c}\text { Upper Bond } \\
\mathrm{I}(1)\end{array}$ & \\
\cline { 2 - 3 } $10 \%$ & 2.08 & 3 & \multirow{3}{*}{$\mathbf{3 6 2 9 1 3}$} \\
$5 \%$ & 2.39 & 3.38 & \\
$2.5 \%$ & 2.7 & 3.73 & \\
$1 \%$ & 3.06 & 4.15 &
\end{tabular}

Results of Bound Test Approach to Cointegration for Model 19

\begin{tabular}{cccc}
\hline Significance & \multicolumn{2}{c}{ Critical Value Bonds } & Computed F-Statistic \\
\hline & $\begin{array}{c}\text { Lower Bound } \\
\text { I(0) }\end{array}$ & $\begin{array}{c}\text { Upper Bond } \\
\text { I(1) }\end{array}$ & \multirow{2}{*}{$\mathbf{4 . 0 3 2 6 0 3}$} \\
\cline { 2 - 3 } $10 \%$ & 2.26 & 3.35 & \\
$5 \%$ & 2.62 & 3.79 & \\
$2.5 \%$ & 2.96 & 4.18 & \\
$1 \%$ & 3.41 & 4.68 &
\end{tabular}

Results of Bound Test Approach to Cointegration for Model 20

\begin{tabular}{ccc}
\hline Significance & \multicolumn{2}{c}{ Critical Value Bonds } \\
\hline & $\begin{array}{c}\text { Lower Bound } \\
\mathrm{I}(0)\end{array}$ & $\begin{array}{c}\text { Upper Bond } \\
\mathrm{I}(1)\end{array}$ \\
\cline { 2 - 3 } $10 \%$ & 2.08 & 3 \\
$5 \%$ & 2.39 & 3.38 \\
$2.5 \%$ & 2.7 & 3.73 \\
$1 \%$ & 3.06 & 4.15
\end{tabular}

Computed F-Statistic

3.479758

Source: Author's computation using E-view 10 (2019) 


\begin{tabular}{|c|c|c|c|c|c|c|c|}
\hline & Column I & Column II & Column III & Column IV & Column V & Column VI & Column VII \\
\hline Regressand & $\partial \ln \hat{q}$ & $\partial \ln \hat{q}$ & $\partial \ln I N$ & $\ln F$ & $\ln I$ & $\ln R D$ & $\ln P R$ \\
\hline \multirow[t]{2}{*}{$\begin{array}{c}\text { Explanatory } \\
\text { Variables }\end{array}$} & 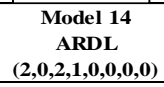 & 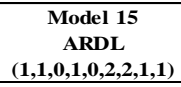 & $\begin{array}{c}\text { Model 16 } \\
\text { ARDL } \\
(\mathbf{2 , 0 , 2 , 2 , 2 , 1 )} \\
\end{array}$ & $\begin{array}{c}\text { Model 17 } \\
\text { ARDL } \\
(\mathbf{2}, \mathbf{0}, \mathbf{0}, \mathbf{0}, \mathbf{0}, \mathbf{0}, \mathbf{0}) \\
\end{array}$ & $\begin{array}{c}\text { Model 18 } \\
\text { ARDL } \\
(\mathbf{1 , 0 , 0 , 0 , 0 , 2 )} \\
\end{array}$ & $\begin{array}{c}\text { Model 19 } \\
\text { ARDL } \\
(\mathbf{1 , 0 , 0 , 0 , 0 , 0 , 1 )} \\
\end{array}$ & 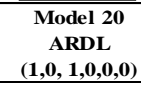 \\
\hline & & & $0.000912 *$ & 0.002334 & $-0.004196^{*}$ & $0.073969 *$ & $-0.001885^{*}$ \\
\hline \multirow{4}{*}{$\partial \ln \hat{q}$} & & & $\{0.006654\}$ & $\{0.001295\}$ & $\{0.001958\}$ & $\{0.115762\}$ & $\{0.004037\}$ \\
\hline & & & [0.137106] & [1.802316] & {$[-2.143463]$} & [0.638974] & {$[-0.466887]$} \\
\hline & & & $\{\{0.8917\}\}$ & $\{\{0.0046\}\}$ & $\{\{0.0382\}\}$ & $\{\{0.5265\}\}$ & $\{\{0.6431\}\}$ \\
\hline & $13.45315^{*}$ & $12.70664 *$ & & & & & \\
\hline \multirow[t]{4}{*}{119} & $\{6.956318\}$ & $\{3.41937\}$ & & & & & \\
\hline & [1.933947] & [3.716076] & & & & & \\
\hline & $\{\{0.0426\}\}$ & $\{\{0.0039\}\}$ & & & & & \\
\hline & $4.303837^{*}$ & $5.214951 *$ & & & & & \\
\hline \multirow[t]{4}{*}{$\partial \ln L$} & $\{2.05824\}$ & $\{2.32331\}$ & & & & & \\
\hline & [2.091027] & {$[0.416085]$} & & & & & \\
\hline & $\{\{0.0189\}\}$ & $\{\{0.0483\}\}$ & & & & & \\
\hline & $0.308421 *$ & $0.286681 *$ & & & & & \\
\hline \multirow[t]{4}{*}{$\partial \ln N$} & $\{3.550469\}$ & $\{3.435252\}$ & & & & & \\
\hline & {$[0.086868]$} & {$[0.083452]$} & & & & & \\
\hline & $\{\{0.9538\}\}$ & $\{\{0.9997\}\}$ & & & & & \\
\hline & $0.315610^{*}$ & $0.021740^{*}$ & $0.071364 *$ & $0.453844^{*}$ & $-0.105839 *$ & $0.004369^{*}$ & $-0.129231^{*}$ \\
\hline \multirow[t]{4}{*}{$\ln F$} & $\{5.405735\}$ & $\{5.111789\}$ & $\{0.202675\}$ & $\{0.073652\}$ & $\{0.069829\}$ & $\{0.006027\}$ & $\{0.144428\}$ \\
\hline & [0.058384] & {$[0.004253]$} & {$[0.35211]$} & [6.161992] & {$[-1.515675]$} & [0.724989] & [0.894776] \\
\hline & $\{\{0.9538\}\}$ & $\{\{0.9966\}\}$ & $\{\{0.7267\}\}$ & $\{\{0.0005\}\}$ & $\{\{0.1375\}\}$ & $\{\{0.4727\}\}$ & $\{\{0.3763\}\}$ \\
\hline & $5.047328 *$ & $7.339274 *$ & $0.050241 *$ & $0.341820^{*}$ & & $-0.001670^{*}$ & $-0.101549 *$ \\
\hline \multirow[t]{4}{*}{$\ln I$} & $\{2.449401\}$ & $\{2.013432\}$ & $\{0.219698\}$ & $\{0.068612\}$ & & $\{0.006582\}$ & $\{0.135646\}$ \\
\hline & {$[2.060638]$} & [3.645156] & {$[0.228681]$} & [4.981896] & & {$[-0.25381]$} & {$[-0.748632]$} \\
\hline & $\{\{0.0000\}\}$ & $\{\{0.0005\}\}$ & $\{\{0.8203\}\}$ & $\{\{0.0016\}\}$ & & $\{\{0.8009\}\}$ & $\{\{0.4585\}\}$ \\
\hline & $-7.023664 *$ & $-8.070993 *$ & $0.34182 *$ & $0.073969^{*}$ & $-0.017968 *$ & $0.002378^{*}$ & $-0.209057 *$ \\
\hline \multirow[t]{3}{*}{$\ln T$} & $\{4.613507\}$ & $\{2.247637\}$ & $\{1.391093\}$ & $\{0.013992\}$ & $\{0.029209\}$ & $\{0.002082\}$ & $\{0.041041\}$ \\
\hline & {$[-1.522413]$} & {$[-3.590879]$} & [0.245720] & [5.286661] & {$[-0.61515]$} & [1.142134] & {$[-5.093865]$} \\
\hline & $\{\{0.0000\}\}$ & $\{\{0.0000\}\}$ & $\{\{0.8072\}\}$ & $\{\{0.0011\}\}$ & $\{\{0.5419\}\}$ & $\{\{0.2602\}\}$ & $\{\{0.0004\}\}$ \\
\hline \multirow{4}{*}{$\ln G$} & $-2.7023664 *$ & $-6.93779^{*}$ & $-0.015552^{*}$ & $0.654663 *$ & $-0.652238^{*}$ & $0.714514 *$ & $-0.181760 *$ \\
\hline & $\{1.1395427\}$ & $\{3.64887\}$ & $\{0.006107\}$ & $\{0.139107\}$ & $\{0.190872\}$ & $\{0.109658\}$ & $\{0.039880\}$ \\
\hline & {$[-2.371448]$} & {$[-1.901353]$} & {$[-2.54657]$} & [4.706170] & {$[-3.417141]$} & [6.515838] & {$[-4.557673]$} \\
\hline & $\{\{0.0237\}\}$ & $\{\{0.0001\}\}$ & $\{\{0.0151\}\}$ & $\{\{0.0022\}\}$ & $\{\{0.0015\}\}$ & $\{\{0.0000\}\}$ & $\{\{0.0316\}\}$ \\
\hline \multirow{4}{*}{$\ln P$} & & $-5.047328 *$ & & & & & \\
\hline & & $\{1.137732\}$ & & & & & \\
\hline & & {$[-4.436307]$} & & & & & \\
\hline & & $\{\{0.0003\}\}$ & & & & & \\
\hline \multirow{4}{*}{$\partial \ln M R$} & & & & $0.016638 *$ & & & \\
\hline & & & & $\{0.004925\}$ & & & \\
\hline & & & & [3.378130] & & & \\
\hline & & & & $\{\{0.0118\}\}$ & & & \\
\hline \multirow{4}{*}{$\partial \ln F R$} & & & & & $-0.893829 *$ & & \\
\hline & & & & & $\{0.066632\}$ & & \\
\hline & & & & & [-13.41438] & & \\
\hline & & & & & $\{\{0.0000\}\}$ & & \\
\hline \multirow{4}{*}{$\mathrm{C}$} & $-2.7023664 *$ & $-7.023664 *$ & $-0.264006^{*}$ & $-6.253265^{*}$ & $3.221401 *$ & $1.18217 *$ & $2.674494 *$ \\
\hline & $\{1.266351\}$ & $\{3.062062\}$ & $\{0.12959\}$ & $\{1.424686\}$ & $\{1.531355\}$ & $\{0.408741\}$ & $\{0.882743\}$ \\
\hline & [2.1339789] & {$[-2.293769]$} & {$[-2.037238]$} & [-4.389223] & [2.103628] & [2.892224] & [3.029753] \\
\hline & $\{\{0.0023\}\}$ & $\{\{0.0369\}\}$ & $\{\{0.0502\}\}$ & $\{\{0.0032\}\}$ & $\{\{0.0417\}\}$ & $\{\{0.0062\}\}$ & $\{\{0.0038\}\}$ \\
\hline \multicolumn{8}{|c|}{ Goodness-of-fit Measures } \\
\hline$R^{2}$ & 0.979887 & 0.998111 & 0.95837 & 0.999993 & 0.980811 & 0.997736 & 0.935816 \\
\hline Adjusted $R^{2}$ & 0.931055 & 0.977772 & 0.907962 & 0.999983 & 0.977452 & 0.997340 & 0.924584 \\
\hline F-statistic & 2.206373 & 2.077699 & 7.168346 & 152276.10 & 219.1298 & 2518.139 & 83.31548 \\
\hline $\begin{array}{l}\text { Prob } \\
\text { (F-statistic) }\end{array}$ & 0.0008730 & 0.0000290 & 0.0000030 & 0.0000000 & 0.0000000 & 0.0000000 & 0.0000000 \\
\hline $\begin{array}{l}\text { Durbin-Watson } \\
\text { Stat }\end{array}$ & 2.048868 & 2.183073 & 1.945700 & 2.208187 & 1.797875 & 1.709269 & 2.014552 \\
\hline
\end{tabular}

Notes:

1. \{ \}, [ ] and $\{\{\}\}$ denote Std. Error, t-Statistic, Probability respectively

2. ***, ** and * depict Obs R-squared, Jacque-Bera Statistic and Coefficient respectively

Source: Author's computation using E-view 10 (2019) 


\begin{tabular}{|c|c|c|c|c|c|c|c|}
\hline & Column I & Column II & Column III & Column IV & Column V & Column VI & Column VII \\
\hline Regressand & $\operatorname{lin} \hat{a}$ & Oln $\hat{a}$ & $\partial \ln I N$ & $\ln F$ & $\ln \pi /$ & $\ln R D$ & $\ln P R$ \\
\hline $\begin{array}{c}\text { Explanatory } \\
\text { Variables }\end{array}$ & $\begin{array}{c}\text { Model 14 } \\
\text { ARDL } \\
(\mathbf{2 , 0 , 2 , 1 , 0 , 0 , 0 , 0 )}\end{array}$ & $\begin{array}{c}\text { Model 15 } \\
\text { ARDL } \\
(\mathbf{1 , 1 , 0 , 1 , 0 , 2 , 2 , 1 , 1 )})\end{array}$ & $\begin{array}{c}\text { Model 16 } \\
\text { ARDL } \\
(2,0,2,2,2,1)\end{array}$ & $\begin{array}{c}\text { Model 17 } \\
\text { ARDL } \\
(\mathbf{2 , 0 , 0 , 0 , 0 , 0 , 0 )}\end{array}$ & $\begin{array}{c}\text { Model 18 } \\
\text { ARDL } \\
(\mathbf{1 , 0 , 0 , 0 , 0 , 2 )} \\
\end{array}$ & $\begin{array}{c}\text { Model 19 } \\
\text { ARDL } \\
(\mathbf{1 , 0 , 0 , 0 , 0 , 1 )} \\
\end{array}$ & $\begin{array}{c}\text { Model 20 } \\
\text { ARDL } \\
(\mathbf{1 , 0 , 1 , 0 , 0 , 0 )}\end{array}$ \\
\hline $\begin{array}{l}\text { Breusch- Godfrey } \\
\text { serial correlation } \\
\text { LM test }\end{array}$ & $\begin{array}{c}2.861839 * * * \\
\{\{0.2391\}\}\end{array}$ & $\begin{array}{c}\text { 7.471799*** } \\
\{\{0.0239\}\}\end{array}$ & $\begin{array}{c}10.20348 * * * \\
\{\{0.0601\}\}\end{array}$ & $\begin{array}{c}4.906454 * * * \\
\{\{0.0860\}\}\end{array}$ & $\begin{array}{c}0.835675 * * * \\
\{\{0.6585\}\}\end{array}$ & $\begin{array}{c}3.564478^{* * * *} \\
\{\{0.1683\}\}\end{array}$ & $\begin{array}{l}0.508131 * * * \\
\{\{0.77560\}\}\end{array}$ \\
\hline $\begin{array}{l}\text { Breusch-Pagan- } \\
\text { Godfrey test for } \\
\text { heteroskedasticity }\end{array}$ & $\begin{array}{c}19.48483 * * * \\
\{\{0.0775\}\}\end{array}$ & $\begin{array}{c}25.74900 * * * \\
\{\{0.0577\}\}\end{array}$ & $\begin{array}{c}8.815054 * * * \\
\{\{0.2662\}\}\end{array}$ & $\begin{array}{c}13.34562 * * * \\
\{\{0.2713\}\}\end{array}$ & $\begin{array}{c}4.494854 * * * \\
\{\{0.7213\}\}\end{array}$ & $\begin{array}{c}8.467642 * * * \\
\{\{0.2932\}\}\end{array}$ & $\begin{array}{c}20.52652 * * * \\
\{\{0.0545\}\}\end{array}$ \\
\hline $\begin{array}{l}\text { ARCH test for } \\
\text { heteroskedasticity }\end{array}$ & $\begin{array}{c}0.138700 * * * \\
\{\{0.7096\}\}\end{array}$ & $\begin{array}{c}2.542190 * * * \\
\{\{0.1108\}\}\end{array}$ & $\begin{array}{c}0.060224 * * * \\
\{\{0.8061\}\}\end{array}$ & $\begin{array}{c}0.530834 * * * \\
\{\{0.4663\}\}\end{array}$ & $\begin{array}{c}2.455564 * * * \\
\{\{0.1171\}\}\end{array}$ & $\begin{array}{l}0.07783 * * * \\
\{\{0.7803\}\}\end{array}$ & $\begin{array}{c}2.757391 * * * \\
\{\{0.0968\}\}\end{array}$ \\
\hline $\begin{array}{l}\text { Jacque-Bera } \\
\text { normality test }\end{array}$ & $\begin{array}{c}0.812942 * * \\
\{\{0.665998\}\}\end{array}$ & $\begin{array}{c}2.075440 * * \\
\{\{0.354261\}\}\end{array}$ & $\begin{array}{c}1.675152 * * * \\
\{\{0.432758\}\}\end{array}$ & $\begin{array}{c}1.687117 * * \\
\{\{0.430177\}\}\end{array}$ & $\begin{array}{c}0.849894 * * \\
\{\{0.653805\}\}\end{array}$ & $\begin{array}{c}13.44370^{* *} \\
\{\{0.120400\}\}\end{array}$ & $\begin{array}{c}4.649564 * * \\
\{\{0.097805\}\}\end{array}$ \\
\hline $\begin{array}{l}\text { Ramsey RESET } \\
\text { specification test }\end{array}$ & $\begin{array}{l}{[1.717295]} \\
\{\{0.0956\}\}\end{array}$ & $\begin{array}{l}{[1.588929]} \\
\{\{0.1233\}\}\end{array}$ & $\begin{array}{c}{[1.2364]} \\
\{\{0.2241\}\}\end{array}$ & $\begin{array}{c}{[3.13772]} \\
\{\{0.1010\}\}\end{array}$ & $\begin{array}{c}{[2.16643]} \\
\{\{0.3065\}\}\end{array}$ & $\begin{array}{c}{[2.29386]} \\
\{\{0.6105\}\}\end{array}$ & $\begin{array}{l}{[0.527831]} \\
\{\{0.2165\}\}\end{array}$ \\
\hline
\end{tabular}

Notes:

1. \{\}$,[]$ and $\{\{\}\}$ denote Std. Error, t-Statistic, Probability respectively

2. ***, and ** depict Obs R-squared and Jacque-Bera Statistic respectively

Source: Author's computation using E-view 10 (2019) 